\title{
ECOLOGICAL MONITORING AND
}

\author{
COMPLIANCE PROGRAM
}

\section{FISCAL YEAR 1999 REPORT}

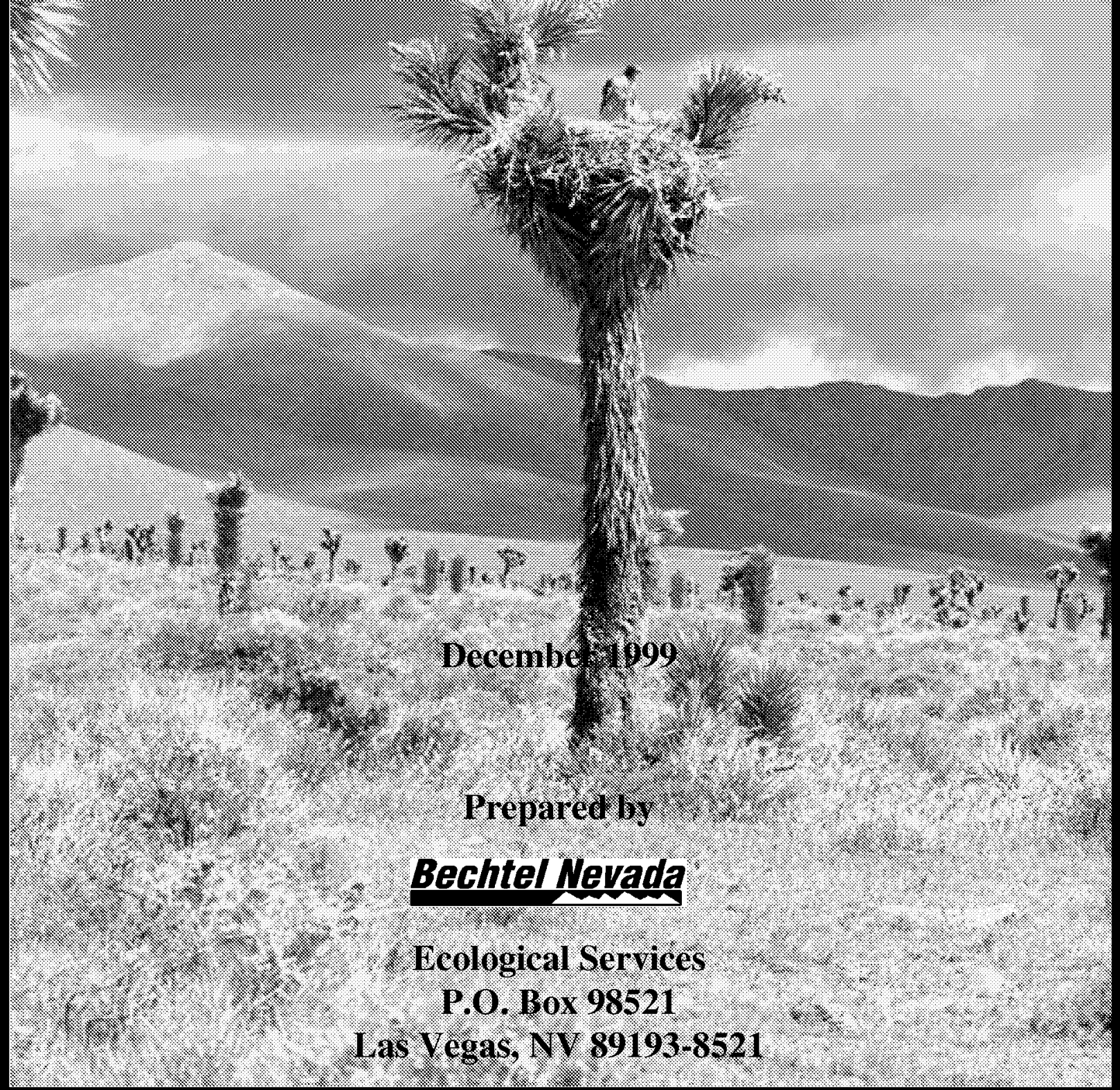




\section{DISCLAIMER STATEMENT}

Reference herein to any specific commercial product, process, or service by trade name, trademark, manufacturer, or otherwise, does not necessarily constitute or imply its endorsement, recommendation, or favoring by the U.S. Government or any agency thereof or its contractors or subcontractors.

\section{AVAILABILITY STATEMENT}

Available for sale to the public from:

U.S. Department of Commerce

National Technical Information Service

5285 Port Royal Road

Springfield, VA 22161-0002

Telephone: $800-553-6847$

Fax: 703-605-6900

E-mail: orders@ntis.fedworld.gov

Online ordering: http://www.ntis.gov/ordering.htm

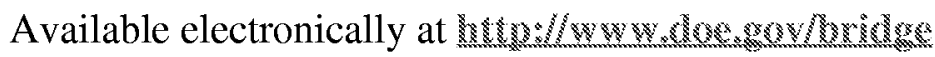

Available for a processing fee to the U.S. Department of Energy and its contractors, in paper, from:

U.S. Department of Energy

Office of Scientific and Technical Information

P.O. Box 62

Oak Ridge, TN 37831-0062

Telephone: $865-576-8401$

Fax: 865-576-5728

E-Mail: reports@adonis.osti.gov 
DOE/NV/11718-387

\section{ECOLOGICAL MONITORING AND COMPLIANCE PROGRAM FISCAL YEAR 1999 REPORT}

December 1999

WORK PERFORMED UNDER

CONTRACT NO. DE-AC08-96NV11718

Prepared for the

U.S. Department of Energy

Nevada Operations Office

Environment, Safety, and Health

P.O. Box 98518

Las Vegas, NV 89193-8518

Prepared by

\section{Bechtel Nevada}

Ecological Services

P.O. Box 98521

Las Vegas, NV 89193-8521 
THIS PAGE IS INTENTIONALLY LEFT BLANK 


\section{CONTENTS}

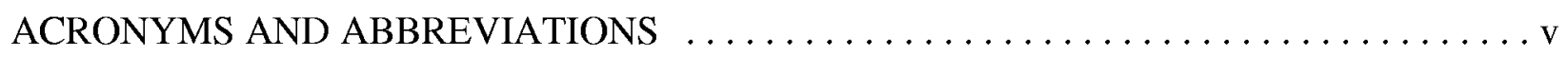



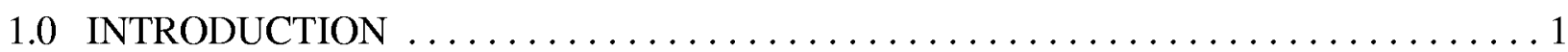



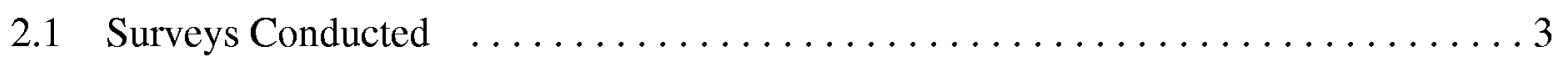

2.2 Use of Survey Data in Meeting RMP Goals $\ldots \ldots \ldots \ldots \ldots \ldots \ldots \ldots$



3.1 Project-related Compliance Activities $\ldots \ldots \ldots \ldots \ldots \ldots \ldots \ldots \ldots$

3.2 Other Compliance Activities . . . . . . . . . . . . . . . . . . . . 10

3.3 Monitoring Parameters and Threshold Levels for Adaptive Management . . . . . . . 11

3.4 Coordination with Desert Tortoise Conservation Biologists . . . . . . . . . . . 12



4.1 NTS Vegetation Habitat Map and Associated Reports . . . . . . . . . . . . . . 13



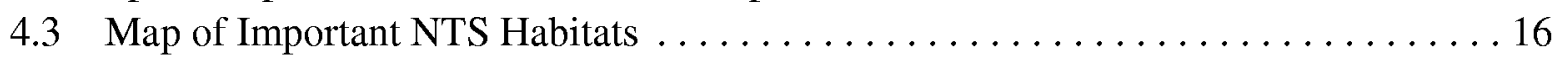

4.4 Development of a Long-term Habitat Monitoring Plan . . . . . . . . . . . 16

4.4.1 Documenting Habitat Changes . . . . . . . . . . . . . . . . . . . 19

4.4.2 Evaluating Environmental Monitoring Techniques . . . . . . . . . . . . . 19

4.4.3 Identifying Habitat Parameters for Monitoring and Threshold Levels for Adaptive

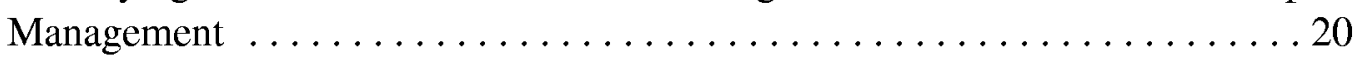

4.5 Coordination with Ecosystem Management Agencies/Scientists . . . . . . . . . 20

5.0 SENSITIVE SPECIES AND HABITAT MONITORING $\ldots \ldots \ldots \ldots \ldots \ldots \ldots .21$

5.1 ESA-protected Species and Species of Concern $\ldots \ldots \ldots \ldots \ldots \ldots \ldots \ldots \ldots$

5.1.1 Candidate Plants and Plant Species of Concern $\ldots \ldots \ldots \ldots \ldots \ldots . \ldots 21$

5.1 .1 .1 Long-term Monitoring Program ................. 21

5.1.1.2 Monitoring Parameters and Threshold Levels for Adaptive Managemêt

5.1.1.3 Clokey's Eggvetch Report ..................... 23

5.1.1.4 Coordination With Natural Resource Agency Botanists . . . . . . . . 23

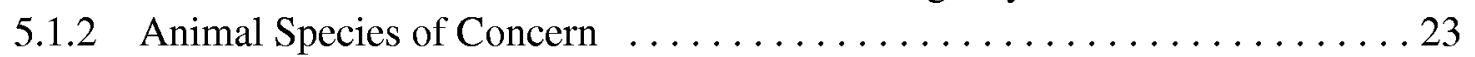

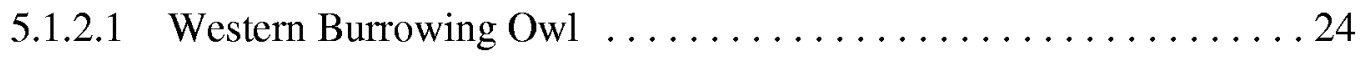

5.1.2.2 Bat Species of Concern . . . . . . . . . . . . . . . . . . . 29

5.2 Other Federally Protected/State-managed Species $\ldots \ldots \ldots \ldots \ldots \ldots \ldots$

5.2 .1 Wild Horses . . . . . . . . . . . . . . . . . . . . . . . . 35

5.2 .1 .1 Abundance Survey . . . . . . . . . . . . . . . . 35

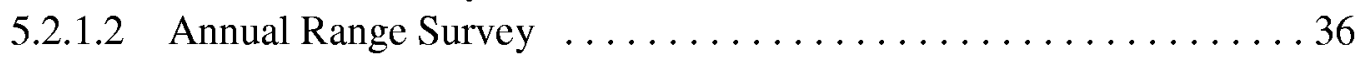


5.2.1.3 Use of NTS Water Sources $\ldots \ldots \ldots \ldots \ldots \ldots \ldots \ldots \ldots \ldots$

5.2.1.4 Identifying Population Size Threshold Level for Adaptive

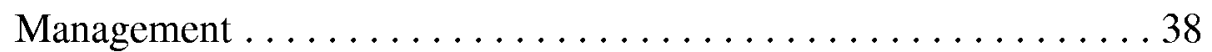



5.2.2.1 Ground Surveys for Nest Sites ..................... 38



5.2.2.3 Identifying Monitoring Parameters and Threshold Levels for

Adaptive Management ...................... 42

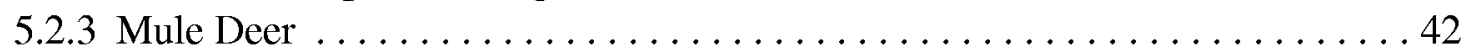

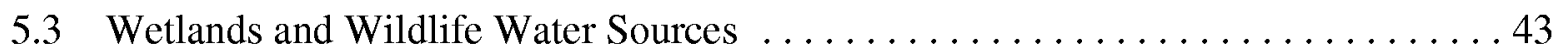

5.3.1 Wetland Delineation of New NTS Natural Water Sources $\ldots \ldots \ldots \ldots . . \ldots 3$

5.3.2 Development of a Routine Wetland Monitoring Plan . . . . . . . . . . . 47

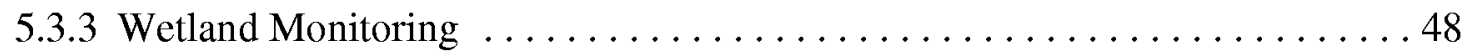

5.3.4 Monitoring of Man-Made Water Sources . .................. 48

6.0 MONITORING OF THE HAZMAT SPILL CENTER $\ldots \ldots \ldots \ldots \ldots \ldots \ldots \ldots \ldots$

6.1 Task Description ........................................ 53

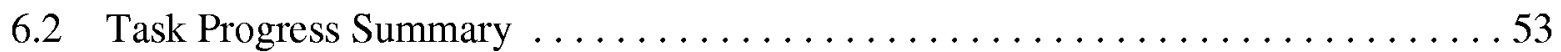

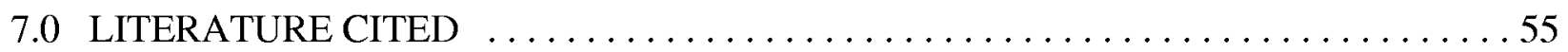

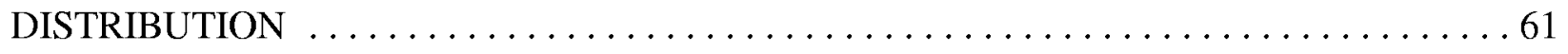




\section{List of Tables}

Table 1. Sensitive species which are protected under state or federal regulations which are known to

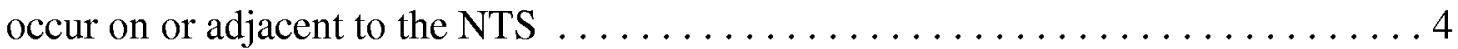

Table 2. Summary of biological surveys conducted on the NTS during FY $1999 \ldots \ldots \ldots 6$

Table 3. Summary of tortoise compliance activities conducted by BN biologists during

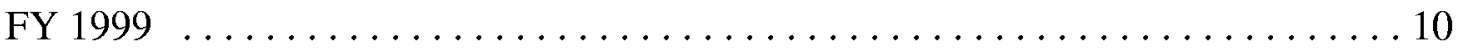

Table 4. Parameters and threshold values for desert tortoise monitoring on the NTS . . . . 11

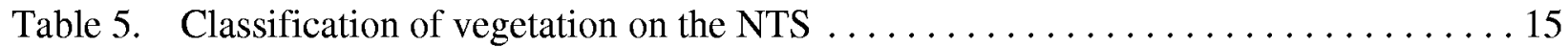

Table 6. Candidate and plant species of concern to be monitored on the NTS $\ldots \ldots \ldots \ldots 22$

Table 7. Summary of burrow use by burrowing owls on the NTS during FY 1999 . . . . . . 26

Table 8. Number of bats by species, gender, and location captured during FY 1999 in three eco-

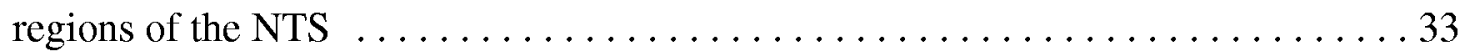

Table 9. Number of horse individuals observed on the NTS by age class, gender (M=male;

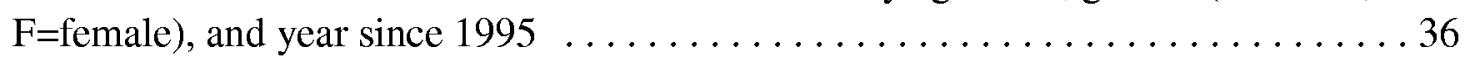



Table 11. Status of known raptor nests found on the NTS ..................... 41

Table 12. Findings on the jurisdictional wetland status of five new NTS water sources

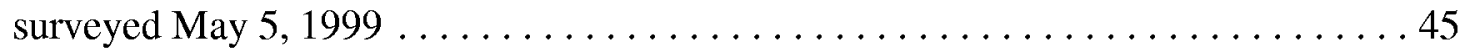

Table 13. Seasonal data from selected natural water sources on the NTS collected during FY 1999 ..................................... 49

Table 14. Seasonal wildlife use at selected springs on the NTS during FY 1999.

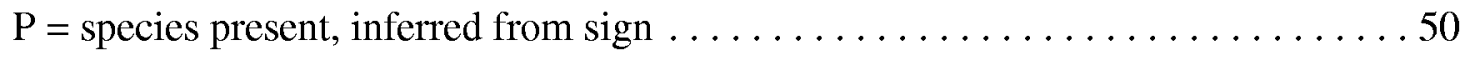

\section{List of Figures}

Figure 1. Biological surveys conducted on the NTS in FY $1999 \ldots \ldots \ldots \ldots \ldots$

Figure 2. Habitat map of vegetation alliances on the NTS $\ldots \ldots \ldots \ldots \ldots \ldots \ldots \ldots \ldots$

Figure 3. Example of ArcView menu used to create plant species distribution maps . . . . . 17



Figure 5. Location of known owl burrows on the NTS during FY $1999 \ldots \ldots \ldots \ldots \ldots \ldots 25$

Figure 6. TM 1500 still camera system set up at an owl burrow (transmitter on right,



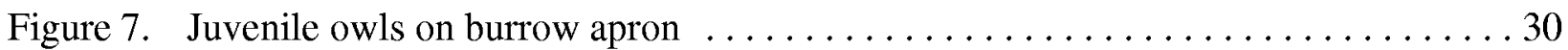

Figure 8. Adult (foreground) and juvenile owl. Juvenile has gray down feathers

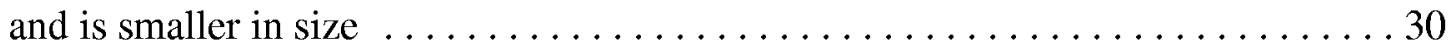

Figure 9. Locations where bat monitoring occurred on the NTS during FY 1999 . . . . . . 31

Figure 10. Feral horse sightings and horse sign observed on the NTS during FY 1999 . . . . . 37

Figure 11. Locations of known raptor nests on the NTS during FY $1999 \ldots \ldots \ldots \ldots \ldots$

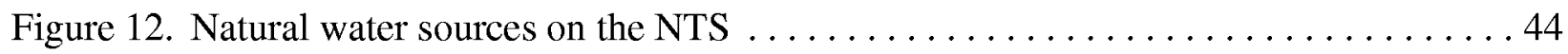

Figure 13. Pahute Mesa Pond wetland in Area 19 of the NTS ..................... 45

Figure 14. View of drainage at Wahmonie Seep \#4 wetland on the NTS . . . . . . . . . 46

Figure 15. Closeup view of pool area at Wahmonie Seep \#4 ................. 46

Figure 16. Man-made water sources monitored for wildlife use and mortality on the NTS




THIS PAGE IS INTENTIONALLY LEFT BLANK 


\section{ACRONYMS AND ABBREVIATIONS}

ac

BLM

$\mathrm{BN}$

CAU

CWA

DNWR

DoD

DOE

DOE/NV

ELU

EMAC

EMAD

EPA

ESA

ESHD

$\mathrm{ft}$

FWS

FY

GIS

ha

HAZMAT

$\mathrm{kHz}$

$\mathrm{km}$

$\mathrm{m}$

mi

$\mathrm{mm}$

NAFR

NNNPS
$\operatorname{Acre}(\mathrm{s})$

U.S. Bureau of Land Management

Bechtel Nevada

Corrective Action Unit

Clear Water Act

Desert National Wildlife Refuge

U.S. Department of Defense

U.S. Department of Energy

U.S. Department of Energy, Nevada Operations Office

Ecological Landform Unit

Ecological Monitoring and Compliance

Engine-Maintenance Assembly and Disassembly

U.S. Environmental Protection Agency

Endangered Species Act

Environment, Safety, and Health Division

Foot/feet

U.S. Fish and Wildlife Service

Fiscal Year

Geographic Information System

Hectare(s)

Hazardous Materials

Kilohertz

Kilometer(s)

Meter(s)

Mile(s)

Millimeter

Nellis Air Force Range

Northern Nevada Native Plant Society 


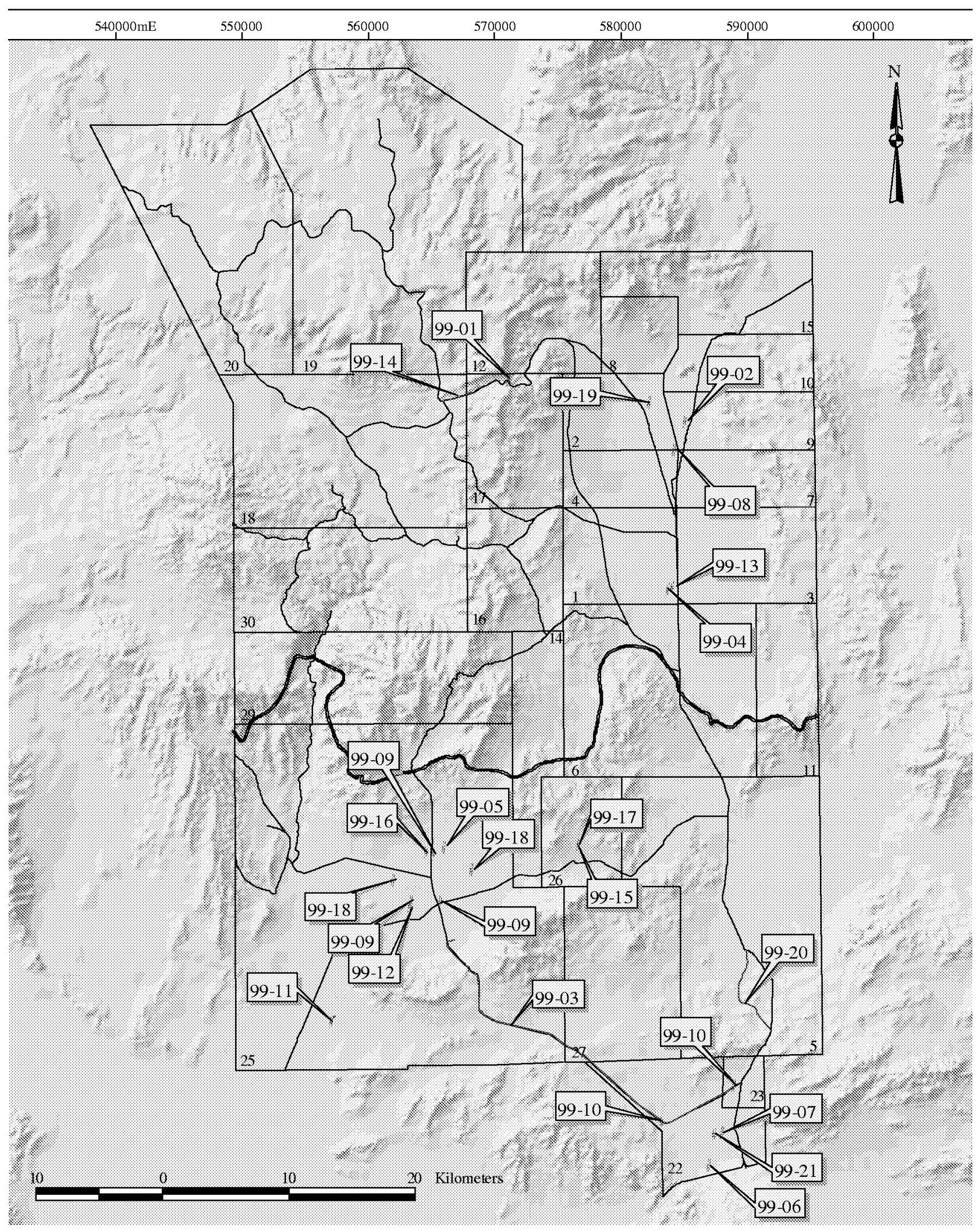

Figure 1. Biological surveys conducted on the NTS in FY 1999 


\subsection{DESERT TORTOISE COMPLIANCE}

The desert tortoise occurs within the southern one-third of the NTS. This species is listed as threatened under the Endangered Species Act (ESA). In December 1995, DOE/NV completed consultation with the U.S. Fish and Wildlife Service (FWS) concerning the effects of DOE/NV activities, described in the Final Environmental Impact Statement for the Nevada Test Site and Off-Site Locations in the State of Nevada (DOE, 1996), on the desert tortoise. A final Biological Opinion (Opinion) (FWS, 1996) was received from the FWS in August 1996. The Opinion concluded that the proposed activities on the NTS were not likely to jeopardize the continued existence of the Mojave population of the species and that no critical habitat would be destroyed or adversely modified. All terms and conditions listed in the Opinion must be followed when activities are conducted within the range of the desert tortoise on the NTS.

The Desert Tortoise Compliance task of EMAC was developed to implement the terms and conditions of the Opinion, to document compliance actions taken by DOE/NV, and to assist DOE/NV in FWS consultations. The terms and conditions that were conducted for DOE/NV by BN staff biologists in FY 1999 included: (1) conducting clearance surveys at project sites within 24 hours from the start of project construction, (2) ensuring that environmental monitors are on-site during heavy equipment operation, (3) ensuring that required tortoise-proof fencing is maintained around open excavations and water impoundments, and (4) preparing an annual compliance report submitted to the FWS.

\subsection{Project-related Compliance Activities}

Biologists conducted desert tortoise clearance surveys prior to ground-disturbing activities at nine proposed NTS project sites (Table 3, Figure 1). Five tortoise burrows and 11 predator burrows, which could be used by a tortoise, were found during surveys for the Jackass Flats to Mercury Fiberoptic Cable (99-03). All five of the tortoise burrows and eight of the predator burrows could not be avoided during cable installation. These 13 burrows were therefore examined with a fiber-optic scope, excavated, and crushed. They were all unoccupied and no tortoise eggs were found in them. Two unoccupied tortoise burrows were found just outside the project area of Corrective Action Unit (CAU) 321 (99-07). One unoccupied tortoise burrow was found inside the project area of CAU 232 (99-16) but it was avoided during project activities. One unoccupied tortoise burrow was found within the project area of CAU 143 (99-18) and will be avoided. Twelve shallow and unoccupied burrows, which could not be avoided, were found along the Burma Road (99-20).

No clearance surveys were conducted prior to land-disturbing activities at three sites (projects 99-06, 99-11, 99-17 [Table 3]). All three of these sites are in areas of "none to very low" tortoise abundance, where clearance surveys are optional, as per the Opinion. Based on 10 post-activity surveys conducted, an estimated 56.21 ac of desert tortoise habitat incurred long-term disturbance from NTS projects during FY 1999 (Table 3).

BN Ecological Services ensured that on-site construction monitoring was conducted by a designated environmental monitor at all eight sites where clearance surveys were performed. 
Table 3. Summary of tortoise compliance activities conducted by BN biologists during FY 1999

\begin{tabular}{|c|c|c|c|}
\hline Project & $\begin{array}{l}\text { Project } \\
\text { Number }\end{array}$ & Compliance Activities & $\begin{array}{l}\text { Tortoise } \\
\text { Habitat } \\
\text { Disturbed (ac) }\end{array}$ \\
\hline $\begin{array}{l}\text { Jackass Flats to Mercury Fiber-optic } \\
\text { Cable }\end{array}$ & $99-03$ & $\begin{array}{l}100 \text { percent-coverage survey, } 13 \text { unavoidable } \\
\text { burrows excavated and crushed, flagged } 3 \\
\text { burrows to avoid, post-activity survey to } \\
\text { document acreage disturbed }\end{array}$ & 46.9 \\
\hline $\begin{array}{l}\text { Characterization of Test Cell A } \\
\text { Leachfields }\end{array}$ & $99-05$ & $\begin{array}{l}100 \text { percent-coverage survey, post-activity } \\
\text { survey }\end{array}$ & 0.27 \\
\hline GEOCORE Alignment Grid & $99-06$ & Post-activity survey & 1.33 \\
\hline $\begin{array}{l}\text { Characterization of Area } 22 \text { Weather } \\
\text { Station Fuel Storage Site (CAU 321) }\end{array}$ & $99-07$ & $\begin{array}{l}100 \text { percent-coverage survey, flagged two } \\
\text { burrows outside project area to avoid, post- } \\
\text { activity survey }\end{array}$ & 4.20 \\
\hline $\begin{array}{l}\text { Characterization of Three Sites in Area } \\
25 \text { (CAU 240) }\end{array}$ & $99-09$ & $\begin{array}{l}100 \text { percent-coverage survey, post-activity } \\
\text { survey }\end{array}$ & 0.99 \\
\hline Sunrise 99 Project & $99-10$ & $\begin{array}{l}100 \text { percent-coverage survey, post-activity } \\
\text { survey }\end{array}$ & 1.38 \\
\hline $\begin{array}{l}\text { Off-road Driving near the Army } \\
\text { Research Laboratory }\end{array}$ & $99-11$ & Post-activity survey & 0 \\
\hline $\begin{array}{l}\text { Characterization of Area } 25 \text { Building } \\
4839 \text { Leachfield (CAU 263) }\end{array}$ & $99-12$ & $\begin{array}{l}100 \text { percent-coverage survey, post-activity } \\
\text { survey }\end{array}$ & 0.30 \\
\hline $\begin{array}{l}\text { Characterization of Test Cell C Sewage } \\
\text { Lagoons (CAU 232) }\end{array}$ & $99-16$ & $\begin{array}{l}100 \text { percent-coverage survey, flagged burrow } \\
\text { for avoidance, post-activity survey }\end{array}$ & 0 \\
\hline Phoenix Facility Pad & $99-17$ & Post-activity survey & 0.84 \\
\hline $\begin{array}{l}\text { Characterization of RMAD and EMAD } \\
\text { waste dumps (CAU 143) }\end{array}$ & $99-18$ & $\begin{array}{l}100 \text { percent-coverage survey, flagged burrow } \\
\text { for avoidance }\end{array}$ & $\begin{array}{l}\text { Not yet } \\
\text { determined }\end{array}$ \\
\hline Burma Road Repairs & $99-20$ & 100 percent-coverage survey & $\begin{array}{l}\text { Not yet } \\
\text { determined }\end{array}$ \\
\hline $\begin{array}{l}\text { Characterization of Area } 22 \text { Sewage } \\
\text { Lagoons/Strainer Box (CAU 230/320) }\end{array}$ & $99-21$ & 100 percent-coverage survey & $\begin{array}{l}\text { Not yet } \\
\text { determined }\end{array}$ \\
\hline Total & & & 56.21 \\
\hline
\end{tabular}

\subsection{Other Compliance Activities}

To ensure the maintenance of required tortoise-proof fences, monitoring was conducted at the dry sump at ER-5-2 Well and at sewage treatment ponds in Areas 6 and 23. The frequency of fence monitoring was reduced last FY from four times a year to once a year at the lagoons (in May) and twice a year at ER-5-2 Well (in May and September). Fence monitoring letter reports were prepared and submitted to ESHD (BN, 1999r; w). The Desert Tortoise Protection brochure was distributed to $329 \mathrm{BN}$ employees and DOE/NV contractors. The brochure is part of the Desert Tortoise Training Program for NTS workers required under the Opinion. 
On January 11, 1999, BN submitted to ESHD the annual report that summarized tortoise compliance activities conducted on the NTS from January 1 through December 31, 1998

(BN, 1999a). This report, required under the Opinion, contains (1) the location and size of land disturbances that occurred within the range of the desert tortoise during the reporting period; (2) the number of desert tortoises injured, killed, or removed from project sites; (3) a map showing the location of all tortoises sighted on or near roads on the NTS; and (4) a summary of construction mitigation and monitoring efforts.

\subsection{Monitoring Parameters and Threshold Levels for Adaptive Management}

Compliance by DOE/NV, their contractors, and other users of the NTS to the FWS Opinion will ensure that the two goals of the DOE/NV RMP are being met; namely, that the desert tortoise is protected on the NTS and that the cumulative impacts on this species are minimized. In the Opinion, the FWS has determined that the "incidental take" of tortoises on the NTS and the cumulative acreage of tortoise habitat disturbed on the NTS (since issuance of the 1992 Opinion) are parameters to be measured and monitored annually. The threshold levels established by the FWS for these parameters are presented in Table 4. Incidental take and acreage disturbance below these limits have been determined to "... not likely jeopardize the continued existence of the Mojave population of the desert tortoise" (FWS, 1996). If any of these limits are exceeded, then FWS requires DOE/NV to re-initiate consultation. BN will, however, re-initiate consultation if these limits are met (i.e., before they are exceeded). This will ensure that NTS projects can continue while consultation is occurring. Reinitiated consultation is the adaptive management action, for it will reassess DOE/NV activities on the NTS, their impact on the species, and the efficacy of mitigation measures that have been performed to minimize take of desert tortoises and to minimize destruction of desert tortoise habitat. During this FY, the threshold values for the monitored parameters were not met (Table 4).

Table 4. Parameters and threshold values for desert tortoise monitoring on the NTS

\begin{tabular}{lcll}
\hline \multicolumn{1}{c}{ Monitored Parameter } & $\begin{array}{c}\text { Threshold } \\
\text { Value }\end{array}$ & $\begin{array}{c}\text { Adaptive Management } \\
\text { Action }\end{array}$ & $\begin{array}{c}\text { Current Value } \\
\text { of Monitored } \\
\text { Parameter }\end{array}$ \\
\hline $\begin{array}{l}\text { Number of tortoises accidentally injured or killed as a } \\
\text { result of NTS activities per year }\end{array}$ & 3 & $\begin{array}{l}\text { Re-initiate consultation with } \\
\text { FWS }\end{array}$ & 0 \\
$\begin{array}{l}\text { Number of tortoises captured and displaced from NTS } \\
\text { project sites per year }\end{array}$ & 10 & $\begin{array}{l}\text { Re-initiate consultation with } \\
\text { FWS }\end{array}$ \\
$\begin{array}{l}\text { Number of total ac of desert tortoise habitat disturbed } \\
\text { during NTS project construction since } 1992\end{array}$ & 3,015 & $\begin{array}{l}\text { Re-initiate consultation with } \\
\text { FWS }\end{array}$ \\
\hline \hline
\end{tabular}

${ }^{1}$ To "take" a threatened or endangered species, as defined by the ESA, is to harass, harm, pursue, hunt, shoot, wound, kill, trap, capture or collect, or attempt to engage in any such conduct. 


\subsection{Coordination with Desert Tortoise Conservation Biologists}

On March 5-7, 1999, a BN biologist attended the Twenty-fourth Annual Meeting and Symposium of the Desert Tortoise Council in St. George, Utah. This symposium is designed to allow exchanges of current information among scientists working with desert tortoise conservation and biology. Over 50 presentations were given and included topics such as ecological effects and management of alien plants in desert tortoise habitat, the latest information on ecology and life history attributes of tortoises, recovery plans and mitigation measures, tortoise nutrition and reproduction, and research on upper respiratory tract disease. A list of abstracts was provided to all participants, and proceedings should be published next year. Presentations were evaluated for the applicability of their field methods, data analysis methods, or study results to tortoise conservation on the NTS.

In September 1999, a BN biologist joined a team of volunteer biologists to assist in the capture, measuring, and weighing of desert tortoises within three 21-ac, circular enclosures in Rock Valley on the NTS. The team is led each year by a biologist from the Biological Resources Division of the U.S. Geological Survey (USGS) and is comprised of biologists from numerous government agencies, universities, and conservation groups (e.g., U.S. Bureau of Land Management, FWS, DOE/NV, University of Nevada at Reno and Las Vegas, and others). The circular enclosures in Rock Valley were constructed during 1962-1963 to study the effects of chronic, low-level ionizing radiation on the desert flora and fauna. At least 24 tortoises have been found in the enclosures, individually marked, and periodically measured and weighed over the decades. There are approximately 18 adult tortoises remaining in the enclosures, and DOE/NV allows USGS and the team of volunteer biologists to visit Rock Valley annually to monitor their growth and survival. These adult tortoises are considered captive by the FWS and are not protected under the 1996 Opinion. This FY 16 tortoises, including one new hatchling, were captured, measured, and weighed. 


\subsection{ECOSYSTEM MAPPING}

In FY 1996, efforts began to map the wildlife and plant habitat of the NTS. Selected biotic and abiotic habitat features were collected within field mapping units called Ecological Landform Units (ELUs). ELUs are landforms with visually similar vegetation, soils, slope, and hydrology. Boundaries of the ELUs were defined using aerial photographs, satellite imagery, and field confirmation. ELUs are considered to be the most feasible mapping unit by which sensitive plant and animal habitats on the NTS can be described.

By the end of FY 1998, field data collection from ELUs was completed, and the production of GISbased maps of NTS habitats began. Efforts this year focused on the production of plant habitat and species-specific distribution maps, development of software scripts needed to produce species-specific maps, design of a long-term habitat monitoring plan, and preparation of a topical report detailing the methods and results of ELU mapping. The GIS-based map products and databases produced by this task will facilitate ecosystem management of the NTS, preparation of future environmental assessments and impact statements, and siting of new NTS projects and facilities.

\subsection{NTS Vegetation Habitat Map and Associated Reports}

A habitat map showing the location of major woodland and shrubland alliances on the NTS was developed based on cluster analysis of vegetation data from over 1,500 ELUs (Figure 2). ELUs were grouped into clusters based on the abundance of shrub/tree species within them. The analysis identified clusters, called vegetation associations, that were named according to the two or three most abundant shrub species found in a cluster. Each cluster of ELUs was then grouped into an alliance, defined by The Nature Conservancy (Grossman et al., 1998; Anderson et al., 1998), as a group of vegetation associations that have the same two to four dominant species. For the purposes of presentation, the vegetation alliances on the NTS were divided into groups characteristic of either the Mojave Desert, the Great Basin Desert, or the Transitional Zone between these two deserts (Table 5). The completed vegetation habitat map was published in the NTS RMP (DOE, 1998).

A draft topical report describing the classification of habitat types on the NTS was prepared during the summer. The report provides a history of prior efforts to classify vegetation on the NTS, including earlier work by Beatley (1976). It describes the major vegetation alliances and their associations, identifies major species, and summarizes associated abiotic features. The report contains newly accepted nomenclature for species (U.S. Department of Agriculture [USDA], 1982; 1996) and vegetation classifications (Anderson et al., 1998) which will facilitate sharing of information with other scientists and adjacent land managers. The draft report is scheduled to be published and distributed in FY 2000.

BN scientists also prepared two papers (Ostler et al., 1999; Hansen et al., 1999) which describe their earlier oral presentations given in FY 1998 at the 10th Wildland Shrub Symposium on August 12-14, 1998, at Snow College in Ephraim, Utah. The papers document how NTS plant alliances and associations were classified, the results of the classification, and other biotic and abiotic parameters associated with each classification. 


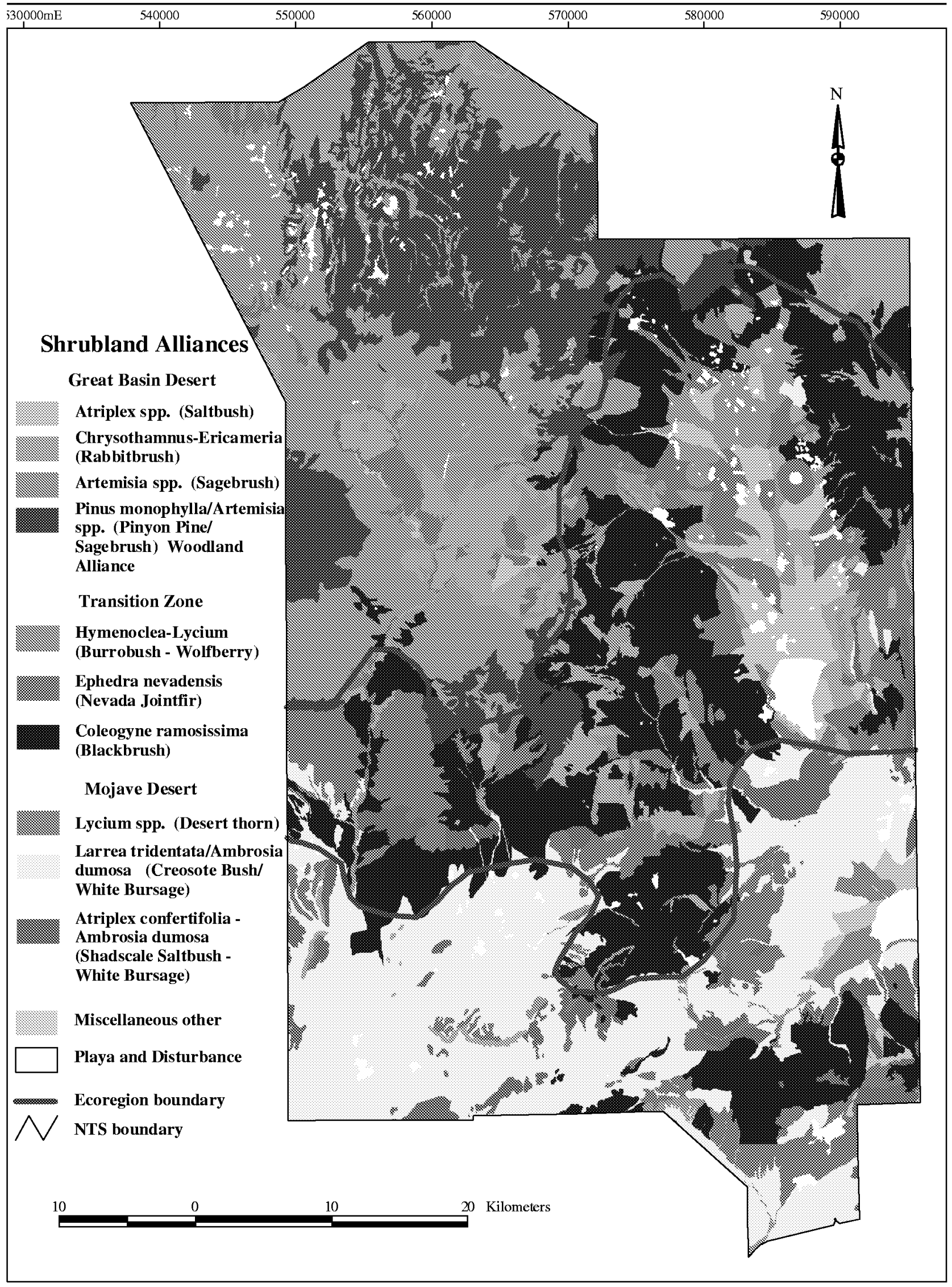

Figure 2. Habitat map of vegetation alliances on the NTS 
ALLIANCE

\[ \text { ALLIANCE } \]
Lycium spp. Shrubland
Larrea tridentata / Ambrosia dumosa Shrubland
Atriplex confertifolia - Ambrosia dumosa
Shrubland

\section{Mojave Desert}

Lycium shockleyi - Lycium pallidum Shrubland

Larrea tridentata / Ambrosia dumosa Shrubland

Atriplex confertifolia - Ambrosia dumosa Shrubland

\section{ASSOCIATION}

\section{Transition Zone}

Hymenoclea - Lycium Shrubland

Ephedra nevadensis Shrubland

Coleogyne ramosissima Shrubland

\section{Great Basin Desert}

Atriplex spp. Shrubland

Chrysothamnus - Ericameria Shrubland

Artemisia spp. Shrubland

Pinus monophylla / Artemisia spp. Woodland
Atriplex confertifolia - Kochia americana Shrubland Atriplex canescens - Krascheninnikovia lanata Shrubland

Chrysothamnus viscidiflorus - Ephedra nevadensis Shrubland

Ericameria nauseosa-Ephedra nevadensis Shrubland

Ephedra viridis - Artemisia tridentata Shrubland

Artemisia tridentata - Chrysothamnus viscidiflorus Shrubland

Artemisia nova - Chrysothamnus viscidiflorus Shrubland Artemisia nova - Artemisia tridentata Shrubland

Pinus monophylla / Artemisia nova Woodland

Pinus monophylla / Artemisia tridentata Woodland

\footnotetext{
${ }^{1}$ Scientific plant names only are used to name alliances and associations as per the Federal Geographic Data Committee and Ecological Society of America (Grossman et al., 1998; Anderson et al., 1998).
} 


\subsection{Species-specific Plant Distribution Maps}

Several hundred GIS-based maps showing the distribution of a single plant species on the NTS by ELU were produced. Plant species included the several hundred trees, shrubs, forbs, grasses, and succulents recorded within ELUs during field sampling. Several ArcView scripts (Microsoft Visual Basic/ArcView programming codes) were created to facilitate the rapid production of these maps. The scripts formatted and printed custom black-and-white or colored maps. The scripts were prepared under subcontract with Applied GIS, Inc., located in Logan, Utah. Examples of the script interface is shown in Figure 3. A collection of several hundred color species maps (8.5 x 11 in format) was produced for future reference. It is not anticipated that these maps will be included in future hard-copy reports because of the expense in reproducing large numbers ( $>1,000$ pages) of colored maps.

However, it is planned that some of the more important species distribution maps will be made available in digital form on a website.

\subsection{Map of Important NTS Habitats}

Analysis of selected biotic and abiotic data collected from ELUs (BN, 1998a) was performed to identify groups of ELUs which may warrant active protection from DOE activities. Four groups of ELUs were identified:

C Pristine - ELUs with few man-made disturbances

C Unique - ELUs containing uncommon biological resources such as a natural wetland

C Sensitive - ELUs containing vegetation associations which recover very slowly from direct disturbance

C Diverse - ELUs with high plant species diversity

These groups are considered important NTS habitats, and a map of their locations was produced (Figure 4). One of the management goals of the DOE/NV RMP is to minimize cumulative impacts on all plants and animals of the NTS. The long-term protection of these important habitats is considered one method by which overall cumulative impacts on biological resources can be minimized. The completed GIS map of NTS important habitats (Figure 4) was included in the published RMP (DOE, 1998). During the siting review for new projects, it is recommended that these habitats be avoided, whenever possible.

\subsection{Development of a Long-term Habitat Monitoring Plan}

Both the vegetation and the important habitat maps completed this FY (Figures 2 and 4) provide a foundation for describing biological resources on the NTS and for quantifying impacts on such resources. The collection of geo-spatial habitat data and the production of these maps was one of several high-priority tasks identified in 1996 by BN Ecological Services in the internal document titled Guiding Principles and Prioritization Criteria for Ecological Monitoring at the Nevada Test Site (see Section 1.0). Efforts began this FY to work on another high-priority task identified in the same 1996 document; the preparation of a written plan for site-wide, long-term monitoring of NTS habitats. 




Figure 3. Example of ArcView menu used to create plant species distribution maps 


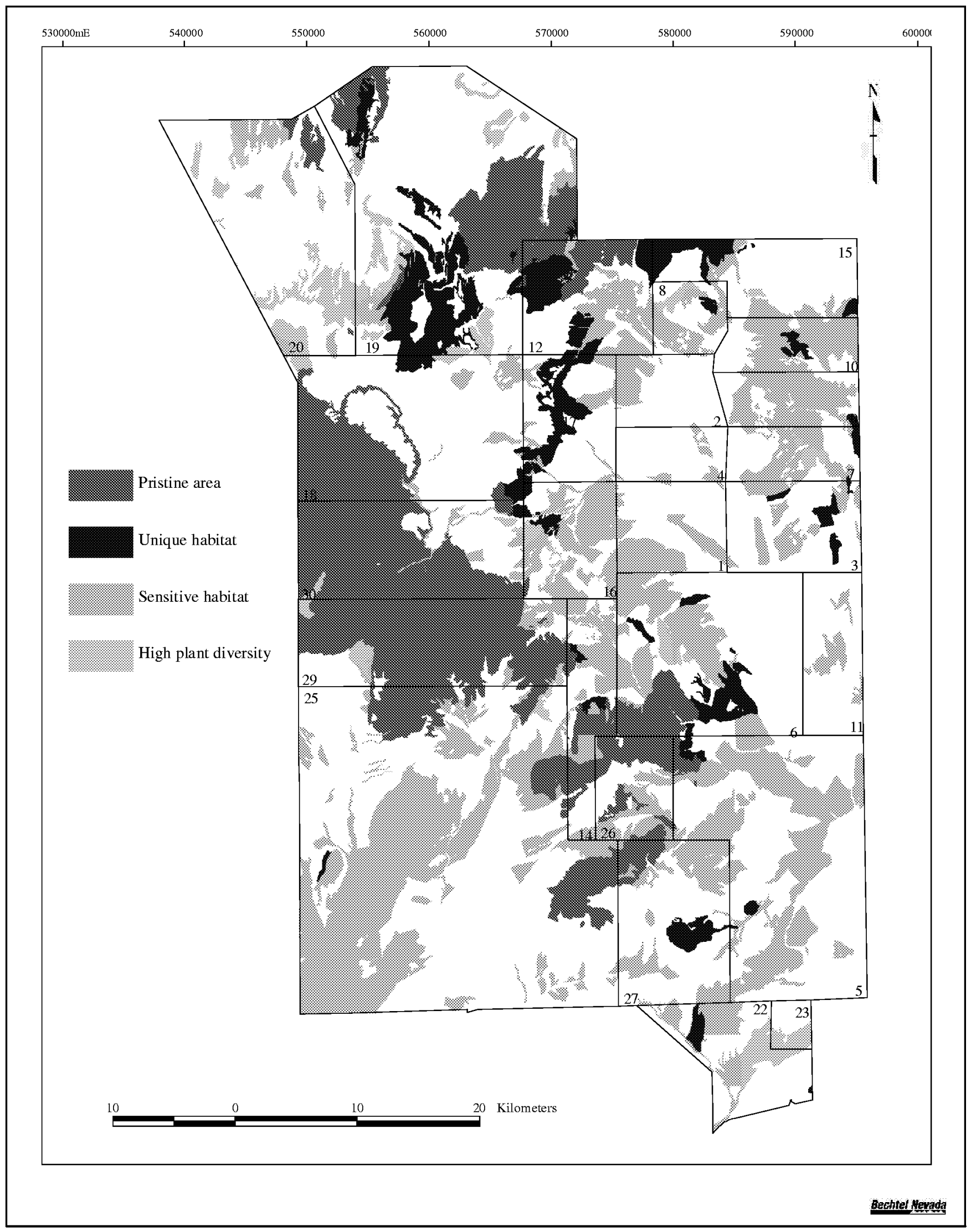

Figure 4. Important habitats on the NTS 
An NTS Habitat Monitoring Plan will identify a subset of habitats, species, and parameters that will be monitored to measure direct and cumulative DOE impacts on NTS habitats. The plan will also describe monitoring techniques and methods, schedules, parameter threshold levels, and adaptive management strategies. It is anticipated that the NTS Habitat Monitoring Plan will be developed throughout FY 2000 and implemented in FY 2001. During the last quarter of this FY, BN scientists started to work on the following sub-tasks related to development of the plan:

- Archive previously collected ecological data that can document habitat changes over time and identify the extent of cumulative DOE impacts versus natural environmental impacts

- Evaluate and develop cost-effective environmental monitoring techniques for rapidly assessing environmental change in ecosystems on the NTS.

\subsubsection{Documenting Habitat Changes}

Ecological monitoring is based on comparisons of site conditions over time. It is therefore important to document major changes and attempt to determine their causal factors, particularly in areas designated as important habitats (see Section 4.3). During FY 1999, DOE/NV allowed biologists from the USGS and the Western Ecological Research Center (WERC) to access two historic biological study plots. $\mathrm{BN}$ biologists assisted the researchers. The plots are located at the historic mining town of Wahmonie in eastern Jackass Flats just north of Cane Springs. The town site is located in the Coleogyne ramosissima - Ephedra nevadensis Association and within an ELU designated as sensitive (see Section 4.3).

The two study plots were photographed and sampled for specific vegetation parameters. USGS and WERC biologists compared 1999 vegetative data with data collected in the 1960s and 1970s and compared current photographs with those taken in the 1970s. Significant changes in species composition, cover, and other biological parameters have occurred over time. These changes, however, do not appear to be related to DOE/NV activities, since the plots have remained undisturbed. It is therefore likely that the changes observed were caused by natural environmental variations in climate, possibly created by El Niño or global warming.

BN biologists will continue to collaborate with outside researchers to document observed changes in NTS habitats through time and their possible causal factors. Some plant data from historical NTS study plots (Beatley, 1979), which had been held in the possession of a private researcher for over 20 years, were provided to BN Ecological Services this year for archival. Efforts will be made next FY to select a database format for the data and linkages to BN's existing ecological geographic information system databases.

\subsubsection{Evaluating Environmental Monitoring Techniques}

The sub-task of evaluating and developing techniques for rapidly assessing environmental change will be achieved through cooperative research sponsored by a Strategic Environmental Research and 
Development Program (SERDP) funded jointly by the Department of Defense (DoD), DOE, and the U.S. Environmental Protection Agency (EPA). A four-year SERDP project titled, "Diagnostic Tools and Reclamation Technologies for Mitigating Impacts of DoD/DOE Activities in Arid Areas," was awarded to BN Ecological Services. BN is managing the project and will share technical responsibilities with scientists from the U.S. Army Corps of Engineers, Fort Irwin, SPSS Inc., Applied Ecological Services, Inc., and California State University at Dominguez Hills. Subcontracted researchers include expert biologists working in the Mojave and Great Basin Deserts.

The objective of the project is to develop a suite of diagnostic techniques (e.g., image analysis of aerial photographs) for rapidly characterizing vegetative parameters. These parameters must distinguish between sustainable and nonsustainable impacts due to DoD and DOE training and testing. The fouryear project will result in a handbook of techniques for monitoring vegetation change in arid Mojave and Great Basin environments. Techniques and results, including software and hardware, will be available to assist $\mathrm{BN}$ biologists with the EMAC habitat monitoring efforts on the NTS.

\subsubsection{Identifying Habitat Parameters for Monitoring and Threshold Levels for Adaptive Management}

Field application of selected monitoring techniques is necessary before the biological parameters to be used in long-term habitat monitoring are chosen. The following parameters, however, were selected as candidate parameters: plant cover and plant community composition. Threshold levels for these and perhaps other habitat parameters will not be selected until FY 2000.

\subsection{Coordination with Ecosystem Management Agencies/Scientists}

BN biologists held discussions with scientists from other government agencies this FY about sharing biological data collected from the NTS and other sites within the Mojave and Great Basin Desert ecosystems. The use of Internet Web sites was identified as the primary and preferred means of posting data cost-effectively. During 1999, BN biologists discussed how best to develop a Web site and what types of information would be made available to the public. Plans were made to develop a Web site during FY 2000 which will make available EMAC published reports (as Adobe Portable Document Format files), digital photographs, maps, summaries of recent and ongoing research, and links to other related biological information. Web site development will facilitate the exchange of information, reduce publication costs, enhance the capabilities of BN to disseminate information, and will invite collaboration with other researchers.

This year, BN Ecological Services received an 8-CD-ROM package of geo-spatial data from DoD which was compiled for the Mojave Desert Ecosystem Program under the DoD Legacy Program. Data in the package includes satellite imagery files as well as soil, vegetation, climate, and other image data for the Mojave Desert. 


\subsection{SENSITIVE SPECIES AND HABITAT MONITORING}

\subsection{ESA-protected Species and Species of Concern}

There are 26 species which occur on the NTS that are considered sensitive because they are either listed as threatened or endangered under the ESA, are current candidates for listing, or are species of concern (Table 1; status codes T, E, or SOC). The desert tortoise is the only threatened or endangered species which could be significantly impacted by DOE/NV activities. EMAC tasks related to the desert tortoise are addressed in Section 3.0 of this report. As with the desert tortoise, the goal of species and habitat monitoring is to ensure the continued presence of all sensitive species on the NTS by protecting them from significant impacts due to DOE/NV actions. A secondary goal is to gather sufficient information on these species' distribution and abundance on the NTS to determine if further protection under state or federal law is necessary. Sensitive species monitoring tasks include field surveys to identify species' distribution and abundance and monitoring of the known population locations, roost sites, and burrows of these species.

Some of the federally protected species and species of concern listed in Table 1 have been sighted on the NTS, however no site-wide surveys to determine their distribution or abundance have been conducted. They include the endangered American peregrine falcon (Falco peregrinus anatum), the candidate mountain plover (Charadrius montanus), and four bird species of concern: the ferruginous hawk (Buteo regalis), least bittern (Ixobrychus exillis hesperis), loggerhead shrike (Lanius ludovicianus), and white-faced ibis (Plegadis chihi). All of these birds, with the exception of the loggerhead shrike, are uncommon transients to the NTS and are not expected to be impacted by NTS activities. Loggerhead shrikes have been observed on the NTS every month of the year and are known to breed on-site. Future surveys for this bird may be planned if state or federal agencies change its status. Records of all bird sightings that are made opportunistically by EMAC biologists and other NTS workers are maintained to provide some data on these species' occurrence on the NTS.

\subsubsection{Candidate Plants and Plant Species of Concern}

\subsubsection{Long-term Monitoring Program}

Clokey's eggvetch (Astragalus oophorus var. clokeyanus) is currently the only candidate plant species known to occur on the NTS. Field surveys to collect baseline data for this plant were initiated in FY 1996 and were completed in FY 1998 (Anderson, 1998). Similar site-wide surveys for twelve plant species of concern were completed in 1995 (Blomquist et al., 1995). No new field surveys for sensitive plants were conducted this FY, and none are planned for the future. Sufficient baseline data has been collected to initiate long-term monitoring of these species.

The locations of all sensitive plant populations on the NTS have been entered into a GIS database. The first phase of monitoring will involve geo-spatial analysis of the plant population data and the biological survey data for proposed projects (see Section 2.0). GIS analysis software (ArcView) will be used to report the number of plant locations that are within a prescribed radius of land-disturbing projects. The total number of plant locations, by species, which contain or are adjacent to a new disturbance, will be tracked. A new disturbance is defined as any project that was not present at the time the plant location 
was first found. To perform this geo-spatial analysis, the geographic coordinates of all project site locations surveyed since 1978 need to be entered into the GIS database. This work was started in June and should be completed by the end of next FY.

The second phase of monitoring will involve field monitoring of selected plant locations to: (1) verify the results of geo-spatial analysis, (2) ensure that unintentional land disturbance has not occured, and (3) assess the degree of impact a disturbance has on an isolated plant population. This phase will not be designed until next FY. The majority of the sensitive plant populations are not threatened by DOE/NV activities, thus field monitoring for most species is expected to be minimal given current land use trends.

\subsubsection{Monitoring Parameters and Threshold Levels for Adaptive Management}

The monitoring parameter for sensitive plants on the NTS will be called the population disturbance index (PDI). This index will be computed for each species (x), by dividing the number of locations of a species that contain a new disturbance (LD) by the total number of locations of that species (L):

$$
\mathrm{PDI}_{(\mathrm{x})}=\mathrm{LD}_{(\mathrm{x})} / \mathrm{L}_{(\mathrm{x})}
$$

This index can range from 0 to 1 . The PDI for each species will be computed next FY when all survey data is entered into the GIS database. No threshold value or adaptive management actions have yet been determined. Table 6 lists the plant species which will be monitored and their total number of known locations on the NTS.

Table 6. Candidate and plant species of concern to be monitored on the NTS

\begin{tabular}{lcc}
\hline \multicolumn{1}{c}{ Plant Species } & $\begin{array}{c}\text { Number of Known } \\
\text { Locations Disturbed } \\
\text { in FY 1999 }\end{array}$ \\
\hline Arctomecon merriamii (White bearpoppy) & $\begin{array}{c}\text { Number of Known } \\
\text { Locations (L) }\end{array}$ & 0 \\
Astragalus beatleyae (Beatley milkvetch) & 17 & 0 \\
Astragalus funereus (Funeral Mountain milkvetch) & 33 & 0 \\
Astragalus oophorus var. clokeyanus (Clokey's eggvetch) & 9 & 0 \\
Camissonia megalantha (Cane Spring evening primrose) & 22 & 0 \\
Cymopterus ripleyi var. saniculoides (Sanicle biscuitroot) & 11 & 0 \\
Frasera pahutensis (Pahute Mesa green gentian) & 18 & 0 \\
Galium hilendiae ssp. kingstonense (Kingston bedstraw) & 9 & 0 \\
Penstemon pahutensis (Pahute Mesa beardtongue) & 5 & 1 \\
Phacelia beatleyae (Beatley phacelia) & 88 & 0 \\
Phacelia parishii (Parish's phacelia) & 41 & 1 \\
\hline \hline
\end{tabular}




\subsubsection{Clokey's Eggvetch Report}

A topical report and GIS-produced map describing the known NTS distribution of Clokey's eggvetch was published this fiscal year (Anderson, 1998). The report was distributed to natural resource management agencies of the state of Nevada and to local and regional FWS offices. The survey work completed on this species has contributed significantly to the overall understanding of this species' distribution and need for protection. Its distribution extends from the Spring Mountains, just west of Las Vegas, Nevada, north to Cedar Pass in the Kawich Range, approximately 70 miles southeast of Tonopah, Nevada. The report concluded that, due to its localized distribution within Nevada, Clokey's eggvetch should be considered a species of concern, but it does not warrant the status of candidate species for listing under the ESA.

\subsubsection{Coordination With Natural Resource Agency Botanists}

On April 6, 1999, BN botanists attended the Northern Nevada Native Plant Society (NNNPS) Rare Plant Committee meeting. This meeting is held annually and provides an opportunity for resource agencies to coordinate their efforts to protect rare plant species and make recommendations regarding species that may need protection under state or federal laws and regulations. Program updates were given by BN botanists and botanists from the FWS, U.S. Forest Service, University of California Berkley, Nevada Division of Forestry, Nevada Natural Heritage Program, The Nature Conservancy (TNC), and the NNNPS. Approximately 30 species were discussed. Three of the species, Clokey's eggvetch, a species of Phacelia which has not yet been taxonomically described, and Beatley's milkvetch occur on the NTS.

During last year's meeting, BN botanists recommended that Clokey's eggvetch be removed from the candidate list under the ESA. This year, BN made the same recommendation and it was approved by the group. The Phacelia species was recommended for addition to the NNNPS sensitive species list last year by a TNC botanist. Once this species has been taxonomically described, surveys to identify the occurrence and distribution of this Phacelia on the NTS will be scheduled for FY 2000 if needed. There was also a recommendation made and approved to remove Beatley's milkvetch from the State Endangered Species list. Meeting minutes are on the internet at:

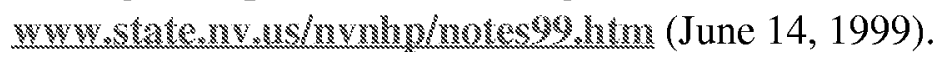

\subsubsection{Animal Species of Concern}

Site-wide surveys for eight animal species of concern were initiated in 1996 (Steen et al., 1997). The species included chuckwalla (Sauromalus obesus), western burrowing owls (Speotyto cunicularia), and six species of bats (Table 1). For chuckwalla, presence/absence data were gathered from selected rocky habitats in the southern portion of the NTS. These data were considered sufficient to identify chuckwalla habitat on the NTS. Proposed activities on the NTS are primarily within valleys, on northern mesas, or on level or gently sloping terrain, and do not include typical chuckwalla habitat. DOE/NV impacts on chuckwalla will be monitored over time by identifying all historic and new projects that have or will disturb chuckwalla habitat. This will be done through geo-spatial analysis using the GIS display and analysis software, ArcView. No new field surveys for chuckwalla were conducted this FY. 
Collection of baseline data on western burrowing owls and bats continued this FY. Owl monitoring included searching for new burrows, visiting known burrows monthly to detect owl activity, and using still and video cameras at burrows to detect reproductive activity. Bat monitoring this year included mist-netting at selected NTS water sources and Anabat surveys (i.e., using an Anabat II recording system to document species-specific ultrasonic bat calls). Anabat surveys were conducted seasonally along roads and at the entrances of mines and tunnels.

\subsubsection{Western Burrowing Owl}

New Burrow Surveys - Transect surveys to locate new owl burrows were conducted across the NTS to better define the distribution of this species. This year, transect surveys were conducted in areas away from man-made disturbances such as roads, drill pads, etc. In previous years, surveys were conducted mainly along roads, and the distribution map of known burrows reflects this bias. Survey areas were chosen subjectively, and meandering transects were walked by one or two biologists through each survey area. At each new owl burrow the following data were recorded: Universal Transverse Mercator coordinates; burrow type (e.g., predator-excavated burrow, culvert burrow); height, width, and aspect of burrow entrance; and the presence/absence and estimated age of owl sign. The burrow location was marked on a topographic map. All survey data were entered into an Access database.

Twenty-four transect surveys covering approximately 76 kilometers $(\mathrm{km})$ (47 miles [mi]) were conducted throughout the NTS. Nine new owl burrows were located, all of which are in natural, undisturbed habitat. Two of the nine burrows were excavated by tortoises (based on burrow shape and/or presence of tortoise scat), and the remaining seven were predator-excavated burrows.

An additional 19 owl burrows were found opportunistically or while conducting other resource surveys. Four of these are in undisturbed habitat and 15 are in disturbed habitat, including man-made structures (e.g., predator-excavated burrow in the side of a road cut, burrow inside a metal culvert). Figure 5 shows the distribution of the 64 known owl burrows on the NTS. These include the 28 burrows found this year and the 36 previously known (historic) burrows. Of the 64 known owl burrows, 40 are in disturbed habitat and 24 are in undisturbed habitat.

Monitoring of Known Burrows to Detect Owl Use - In order to identify the seasons of immigration, emigration, and breeding of owls within the three eco-regions of the NTS, known burrows were monitored on a monthly basis from November 1998 to September 1999. During February and March, burrows were monitored bi-weekly to better determine when spring-migrating owls arrive at the NTS. Sixty-one of the 64 known burrows were monitored. Two burrows in the Transition Zone are in radiologically controlled areas, and one burrow in the Mojave Desert could not be found.

Each time a burrow was visited, all owl sign on and around the burrow apron and under perching sights near the burrow (i.e., pellets, scat, prey remains, feathers, and tracks) were documented and then removed. This technique enabled BN biologists to document monthly or bi-weekly owl activity at each burrow. The results of burrow monitoring are presented in Table 7. The number 


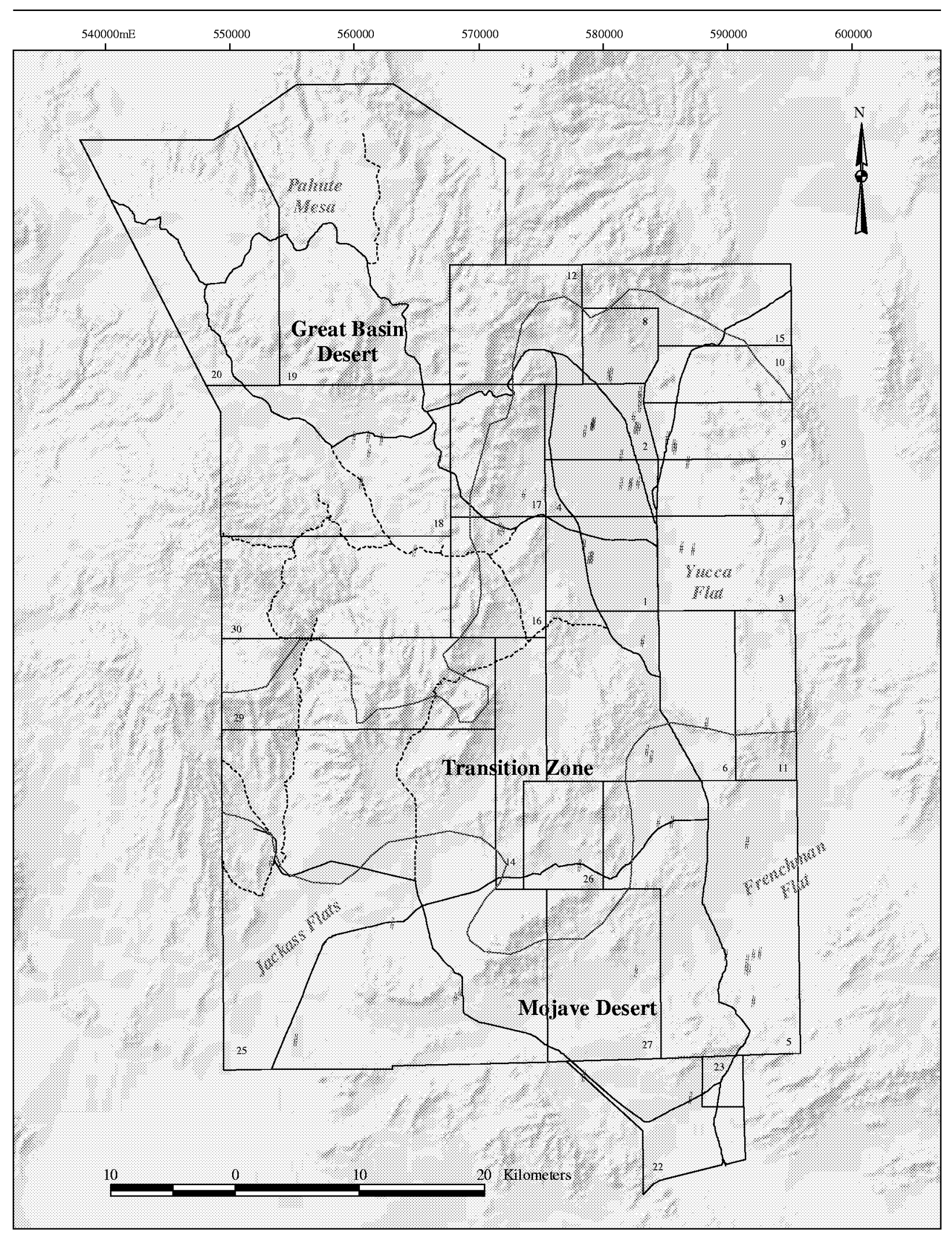

Figure 5. Location of known ow burrows on the NTS during FY 1999 
Table 7. Summary of burrow use by burrowing owls on the NTS during FY 1999

\begin{tabular}{|c|c|c|c|c|c|c|}
\hline \multirow{3}{*}{$\begin{array}{l}\text { Sampling Period } \\
\text { Nov } 24^{* *}\end{array}$} & \multicolumn{6}{|c|}{ Burrow Use* } \\
\hline & \multicolumn{2}{|c|}{ Mojave Desert } & \multicolumn{2}{|c|}{ Transition Region } & \multicolumn{2}{|c|}{ Great Basin Desert } \\
\hline & $4 / 10$ & $(40)$ & $9 / 22$ & $(41)$ & $6 / 6$ & $(100)$ \\
\hline Nov 25 - Dec 9 & $3 / 7$ & (43) & $6 / 22$ & $(27)$ & $4 / 6$ & $(67)$ \\
\hline Dec $10-\operatorname{Jan} 19$ & $1 / 8$ & (13) & $6 / 22$ & $(27)$ & $4 / 6$ & $(67)$ \\
\hline Jan 20 - Feb 2 & $0 / 8$ & $(0)$ & $7 / 24$ & (29) & $1 / 6$ & (17) \\
\hline Feb 3 - Feb 17 & $3 / 9$ & (33) & $5 / 24$ & (21) & $1 / 6$ & (17) \\
\hline Feb 18 - Mar 3 & $1 / 12$ & (8) & $9 / 25$ & (36) & $0 / 6$ & $(0)$ \\
\hline Mar 4 - Mar 18 & $2 / 10$ & $(20)$ & $6 / 25$ & (24) & $1 / 6$ & (17) \\
\hline Mar 19 - Mar 30 & $3 / 12$ & (25) & $8 / 26$ & $(31)$ & $3 / 6$ & $(50)$ \\
\hline Mar $31-A p r 21$ & $3 / 16$ & (19) & $10 / 30$ & (33) & $3 / 6$ & $(50)$ \\
\hline Apr 22 - May 24 & $2 / 14$ & (14) & $14 / 35$ & $(40)$ & $6 / 7$ & $(86)$ \\
\hline May 25 - Jun 29 & $2 / 13$ & (15) & $12 / 34$ & (35) & $5 / 7$ & (71) \\
\hline Jun 30 - Aug 4 & $3 / 11$ & (27) & $12 / 35$ & (34) & $3 / 7$ & (43) \\
\hline Aug 5 - Aug 31 & $2 / 11$ & (18) & $13 / 35$ & (37) & $4 / 7$ & $(57)$ \\
\hline Sep $1-\operatorname{Sep} 30$ & $4 / 14$ & (29) & $10 / 35$ & (29) & $3 / 7$ & $(43)$ \\
\hline Average Percent Use & \multicolumn{2}{|c|}{22} & \multicolumn{2}{|c|}{32} & \multicolumn{2}{|c|}{49} \\
\hline Total Burrows Sampled & \multicolumn{2}{|c|}{19} & \multicolumn{2}{|c|}{35} & \multicolumn{2}{|c|}{7} \\
\hline
\end{tabular}

*Numerator - Number of burrows where sign was found.

Denominator - Number of burrows sampled.

() - Percent of sampled burrows where sign was found.

**All burrows were sampled this day. Owl sign observed at the burrows were deposited over varying time periods ranging from April to August corresponding to the day each burrow was last monitored in FY 1998.

of burrows visited within each region varied across sampling periods for the following reasons:

(1) new burrows were found during the sampling period; (2) some burrows became filled-in during the sampling period and were, therefore, sampled at less-frequent intervals; and (3) not all burrows could be sampled due to time constraints.

Active burrows in the Mojave Desert portion of the NTS declined from November to January until no use was detected in late January to early February. Over the remainder of the sampling period, only two to four burrows were active. These data suggest that there was not an influx of spring migrants into this eco-region during the sampling period.

In the Transition Zone of the NTS, the number of active burrows was lowest (5) in early February. The largest number of active burrows (14) was detected between April 22 and May 24. 
Also, four new active sites were found during this period which had not been monitored throughout winter and early spring. It is therefore difficult to determine if an influx of spring-migrating owls occurred during the April 22 to May 24 sampling period.

The number of active burrows in the Great Basin Desert declined steadily from late November to early March when no active burrows were detected. After this, active burrows increased and reached a maximum of six between April 22 and May 24. These data suggest that an influx of owls occurred between April 22 and May 24 and strengthen the assumption that a similar influx occurred in the Transition Zone during the same time period.

The average percent of active burrows among known burrows was the highest in the Great Basin Desert and lowest in the Mojave Desert portion of the NTS (Table 7). The percent of active burrows detected was the most consistent in the Transition Zone throughout the sampling period. These data suggest that owls are more likely to be found year-round in the Transition Zone of the NTS than in the Mojave or Great Basin Desert eco-regions. The percentage of active burrows within each eco-region observed this FY was similar to last year (BN, 1998a).

During burrow monitoring, pairs of owls were recorded when observed. In the Transition Zone, pairs were detected at nine sites between February 17 and August 31. In the Great Basin Desert ecoregion, a pair was seen at one site on August 4. No pairs were seen during burrow monitoring in the Mojave Desert eco-region. These data suggest that the breeding season may begin as early as midFebruary and continue through August. Emigration was not detected during the sampling period but may occur later in the fall.

Passive Monitoring of Known Burrows to Detect Reproductive Activity - It is important to know trends in owl populations to determine if this species is being affected by DOE/NV activities. One of the best parameters to measure owl population trends is the number of breeding pairs. To measure this number would require several hundred person-hours of direct observation in the field each year. Active infrared beam and camera technology is currently available which allows automated still and video cameras to photograph animal activity in the field. This passive data collection method can allow BN biologists to set up a camera system at an owl burrow and then leave, greatly reducing the time and expense of monitoring breeding activity at a burrow. Three such commercially available systems were used this FY to monitor burrows for reproductive activity: two Trailmaster TM1500s (still camera) and one TM700v (video camera).

The camera systems were set up at burrows where owls or abundant owl sign had been observed during burrow monitoring surveys. At selected burrows, a TM1500 camera was mounted to a fence post approximately 3-5 meters (m) from the burrow with the camera focused directly on the entrance. The infrared beam transmitter and receiver were placed on opposite sides of the burrow entrance (Figure 6). When the beam of infrared light between the transmitter and receiver is broken, the receiver records an "event" and the date and time of the event. An owl entering or exiting the burrow will break the light beam. Each event also triggers the camera to take a picture. Because several events can take place in a short period of time (one owl can walk back and forth in front of the beam several times a minute), the TM1500 was set to take a picture no 


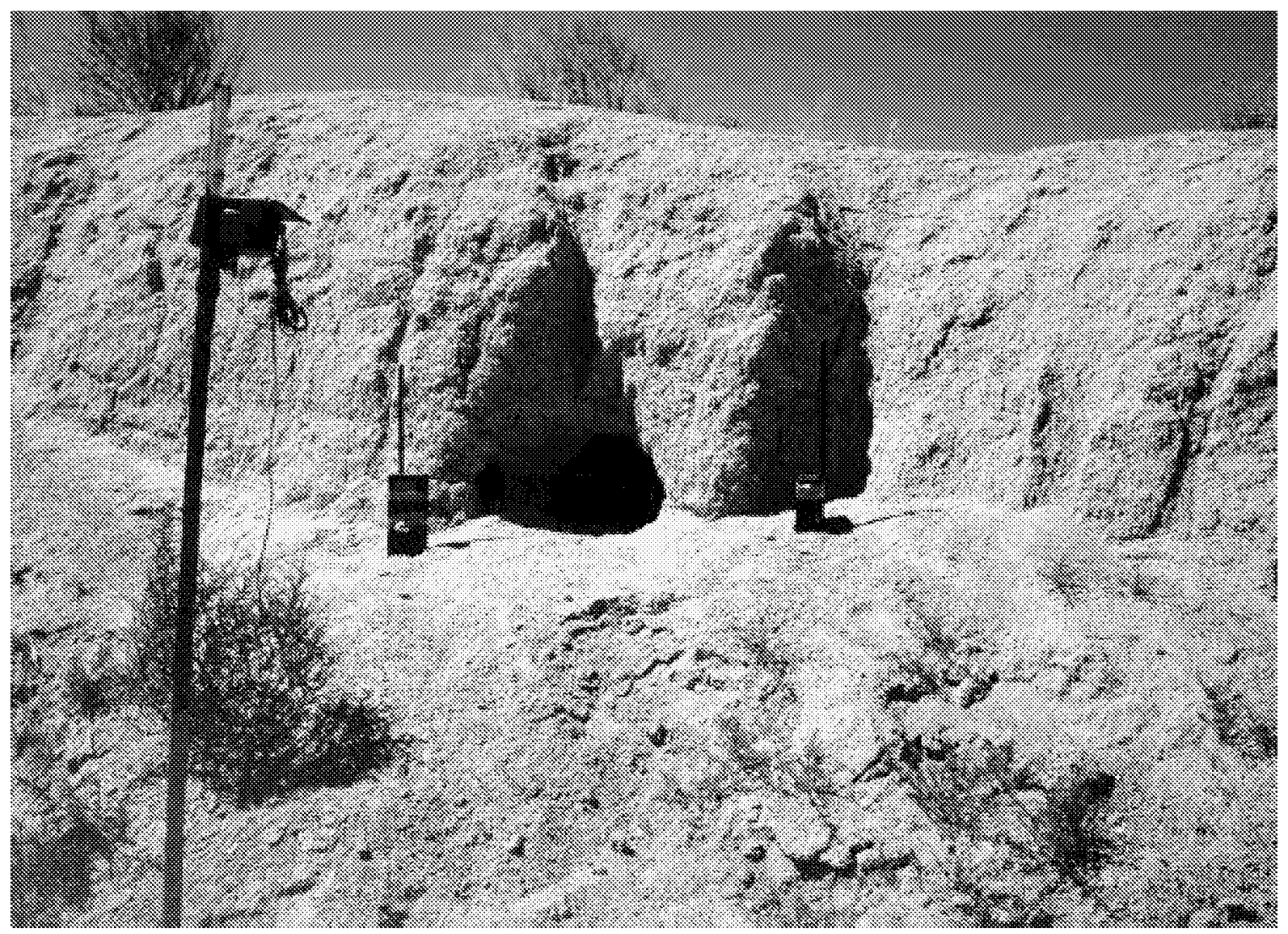

Figure 6. TM 1500 still camera system set up at an owl burrow (transmitter on right,
receiver on left)

more than once every 30 minutes between events. Thus, not every event recorded by the TM1500 receiver was recorded on film. TM1500s were left in place usually for two or three days and then moved to a new burrow location. Exposed film was retrieved and developed within a few days.

The TM700v video camera system was acquired late in the season and recorded burrow activity at only one burrow. This system detects heat and motion combined. When heat and motion (e.g., animal activity) are detected, an event is recorded (date and time), and an 8-millimeter ( $\mathrm{mm}$ ) video camera is turned on to record for a specified amount of time. One minute was selected as this recording time, and 120-minute tapes were used. Recorded tapes were played back and owl and other animal activity was documented.

Nineteen burrow sites were monitored using the TM1500 systems between June 3 and September 9. Three sites were monitored in the Mojave Desert, 13 sites in the Transition Zone, and 3 sites in the Great Basin Desert portions of the NTS. No breeding pairs or young owls were detected in the Mojave Desert eco-region. Young owls (Figure 7) were detected at 4 of the 13 sites sampled (31 percent) in the Transition Zone with a total of 14 young ( 3 to 5 per burrow) observed. In the Great Basin Desert portion of the NTS, young owls were detected at all 3 sites sampled with a total of 10 young ( 1 to 6 per burrow) observed. These data suggest that prey may be more abundant and that overall owl habitat is better in the Transition Zone and Great Basin Desert portions of the NTS than in the Mojave Desert portion. Juvenile owls were easily distinguished from adult owls from about June to 
mid-August based on coloration, presence of gray downy-feathers, size, and lack of barring patterns on young owls (Figure 8).

During early September, the TM700v system recorded four different owls using a culvert burrow on a drill pad in Area 8, but it was impossible to distinguish juveniles from adults. A badger (Taxidea taxus), a major predator of burrowing owls, was also filmed approaching the burrow when four owls were present. Two of the owls at the burrow entrance flushed, but the two perched on a dirt mound 1$2 \mathrm{~m}$ (3-6 ft) away did not flush. The badger sniffed the entrance and then walked away. A few seconds later the other two owls returned to the burrow entrance.

When the TM1500 monitoring data are combined with the burrow monitoring surveys, pairs of owls were detected at 13 of the 61 sites ( 21 percent) and young were detected at 7 of the 61 sites (11 percent). Without banding individual owls, it is not known if pairs move from one burrow site to another and, thus, no count of unique owl pairs can be reported. However, based on the TM1500 data, seven different breeding pairs of owls were detected on the NTS this year.

Monitoring Parameters and Threshold Levels for Adaptive Management - Work began in September on revising the burrowing owl monitoring plan. The final draft should be completed in FY 2000. Results from previous monitoring will be incorporated into the revised plan. The plan will identify the parameter(s) that will be monitored to ensure that the goals of the NTS RMP (DOE, 1998) are being met, as they apply to this species. Threshold limits for these parameters will be identified as well as species-specific adaptive management actions.

\subsubsection{Bat Species of Concern}

Monitoring continued this FY to identify the distribution of bat species of concern and their roost sites on the NTS. The Anabat II system (Titley Electronics, Ballina, Australia) was used again this year to record and analyze the species-specific, ultrasonic vocalizations (calls) of free-flying bats. The Anabat II records the calls and saves them to the hard drive of a laptop computer. The minimum frequency, frequency range, slope, and overall pattern of each call sequence is displayed graphically by the Anabat II software. BN biologists then identify which species emitted each call sequence based on the known call parameters for each species (O’Farrell, 1997; Corben et al., 1998).

Anabat surveys were conducted in conjunction with mist-netting at selected water sources. Anabat surveys were also conducted along selected roads and at mine and tunnel sites where bat roosts might occur.

Mist-Net and Anabat Surveys at NTS Water Sources - Mist-netting was conducted primarily at water sources located in the Great Basin Desert portion of the NTS because five of the six bat species of concern have been found only in this eco-region. Five water sources were sampled

(Figure 9). Pahute Lake (October 14), Camp 17 Pond (October 13, May 17, and June 21), and Gold Meadows Spring (June 22) were sampled in the Great Basin portion of the NTS. Well C1 Pond was the only water source sampled in the Transition Zone (September 7), and Wilson's Pond was the only water source sampled in the Mojave Desert portion of the NTS (May 18). 


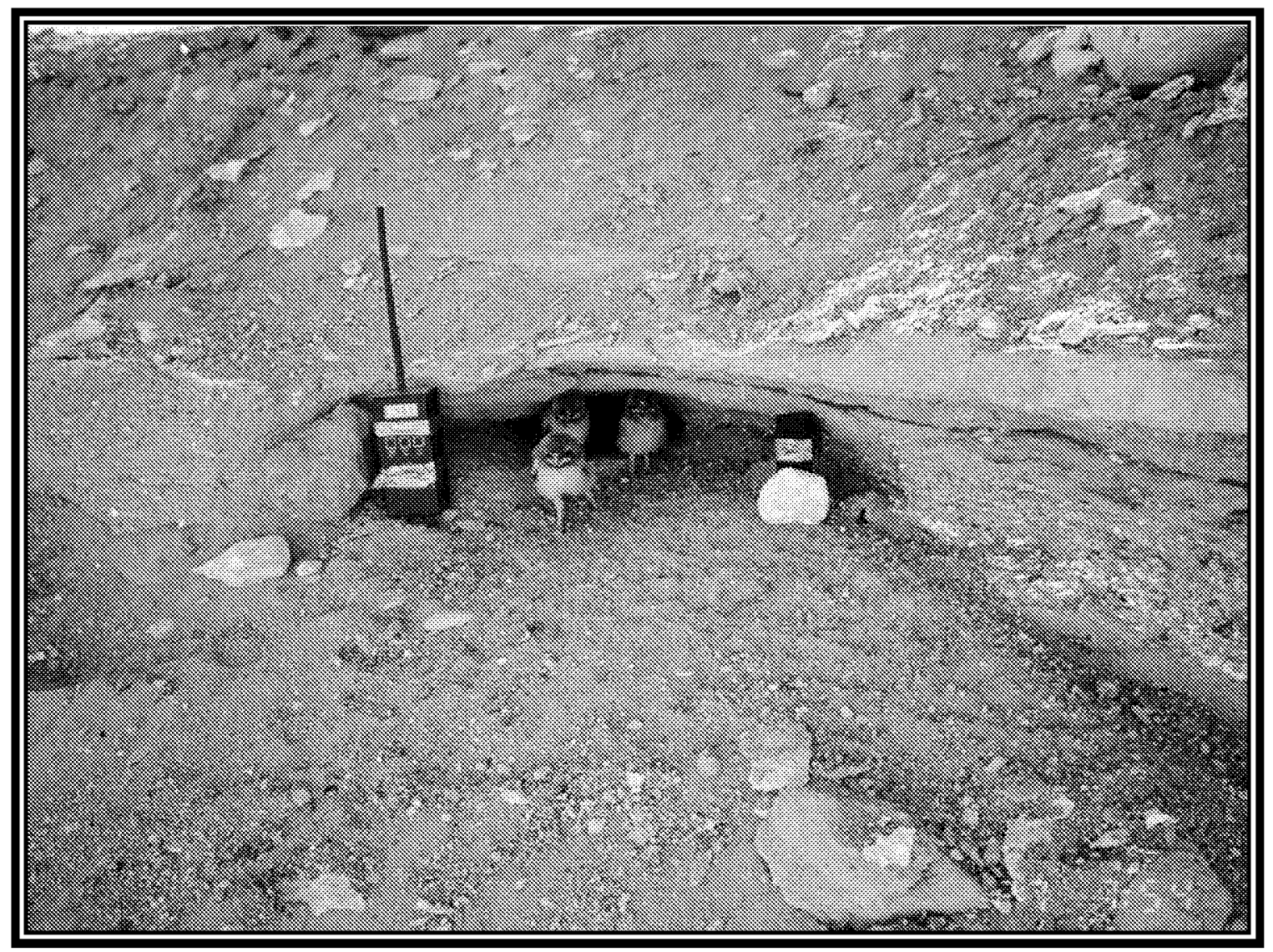

Figure 7. Juvenile owls on burrow apron (photo taken June 27, 1999)



Figure 8. Adult (foreground) and juvenile owl. Juvenile has gray down feathers and is smaller in size (photo taken June 26, 1999) 




Figure 9. Locations where bat monitoring occurred on the NTS during FY 1999 
Eighty bats representing 11 of the 13 species known to occur on the NTS were captured (Table 8). The only two not captured were the pallid bat (Antrozous pallidus) and the spotted bat (Euderma maculatum). Also, the first silver-haired bat (Lasionycteris noctivagans) ever captured on the NTS was captured at Gold Meadows Spring this year. Before this, only a dead specimen collected in Mercury in 1964 had been recorded (M. Saethre, pers. comm., 1996). The calls of the silver-haired bat were also recorded for the first time this year at Camp 17 Pond.

Of the 80 bats captured, 46 were bat species of concern (Table 8). Five different bat species of concern were captured, all within the Great Basin Desert eco-region. No bat species of concern were caught in the other two eco-regions. One female Townsend's big-eared bat (Corynorhinus townsendii) was captured at Camp 17 Pond. This species has the highest likelihood of being listed under the ESA as threatened. Also, the Nevada Division of Wildlife has petitioned the Nevada legislature to protect this species and give it the status of "State Sensitive: Threatened." This female appeared to be lactating, suggesting that there may be a maternity colony near Camp 17 Pond.

Vocal signatures were recorded with the Anabat II system from 10 of the 11 species captured in mist nets and then hand-released. No signature was recorded on the Townsend's big-eared bat. Three California myotis (Myotis californicus) and several small-footed myotis (Myotis ciliolabrum) were captured, measured, hand-released, and their calls recorded. As was found last year, the California myotis had little to no tail extension and a recorded minimum frequency around 50 kilohertz, while the small-footed myotis had a 1-2 mm tail extension and a minimum frequency around 40khz. This is consistent with the findings of Constantine (1998), O'Farrell (1997), and O'Farrell et al. (1999).

Seasonal Anabat Road Surveys - In order to more completely inventory the bat fauna on the NTS, road surveys using the Anabat II bat detection system were initiated in August 1998 and continued through July 1999. These surveys sampled for bats over large areas and across multiple habitats. Driving routes were established in the following four areas of the NTS:

(1) southern NTS (mostly Mojave Desert with some Transition Zone along Cane Spring Road; approximately $101 \mathrm{~km}$ [63 mi] in length); (2) Yucca Flat (Transition Zone; approximately $68 \mathrm{~km}$ [42 mi] in length); (3) Rainier Mesa (Great Basin Desert; approximately $31 \mathrm{~km}$ [19 mi] in length); and (4) Pahute and Buckboard mesas (Great Basin Desert; approximately $76 \mathrm{~km}$ [47 mi] in length) (Figure 9). Routes were purposely designed so that several water sources could be sampled during the surveys. In an attempt to detect species that may be transient migrants on the NTS and detect seasonal differences in bat composition across the NTS, each route was sampled once during fall, spring, and summer except for the southern NTS route which was sampled twice in the summer and not sampled in the fall.

Surveys entailed driving the specified route at speeds of 16-32 kilometers per hour (10-20 miles per hour) with the Anabat microphone held out the window to detect bat activity. When bat activity was detected, the driver slowed down to get as long a call as possible recorded. Along each route, stops were made at water sources and bat calls were recorded for 10-30 minutes at a stop. Surveys began shortly after sunset and continued until the route was finished. 
Table 8. Number of bats by species, gender, and location captured during FY 1999 in three eco-regions of the NTS

\begin{tabular}{|c|c|c|c|c|c|c|}
\hline & & $\begin{array}{r}\text { Great Ba } \\
\text { Desert }\end{array}$ & & $\begin{array}{l}\text { Transition } \\
\text { Zone }\end{array}$ & $\begin{array}{c}\text { Mojave } \\
\text { Desert }\end{array}$ & \\
\hline Species Captured & $\begin{array}{l}\text { Pahute } \\
\text { Lake }\end{array}$ & $\begin{array}{l}\text { Camp } 17 \\
\text { Pond }\end{array}$ & $\begin{array}{c}\text { Gold } \\
\text { Meadows } \\
\text { Spring }\end{array}$ & $\begin{array}{c}\text { Well C1 } \\
\text { Pond }\end{array}$ & $\begin{array}{l}\text { J-11 } \\
\text { Pond }\end{array}$ & Total \\
\hline \multicolumn{7}{|l|}{ Species of Concern } \\
\hline $\begin{array}{l}\text { Corynorhinus townsendii } \\
\text { Townsend's big-eared bat }\end{array}$ & 0 & $\begin{array}{c}1 \\
(1 \mathrm{~F})\end{array}$ & 0 & 0 & 0 & $\begin{array}{c}1 \\
(1 F)\end{array}$ \\
\hline $\begin{array}{l}\text { Myotis ciliolabrum } \\
\text { Small-footed myotis }\end{array}$ & 0 & $\begin{array}{c}10 \\
(7 \mathrm{~F}, 3 \mathrm{M})\end{array}$ & $\begin{array}{c}13 \\
(2 \mathrm{~F}, 11 \mathrm{M})\end{array}$ & 0 & 0 & $\begin{array}{c}23 \\
(9 \mathrm{~F}, 14 \mathrm{M})\end{array}$ \\
\hline $\begin{array}{l}\text { Myotis evotis } \\
\text { Long-eared myotis }\end{array}$ & 0 & 0 & $\begin{array}{c}5 \\
(5 \mathrm{M})\end{array}$ & 0 & 0 & $\begin{array}{c}5 \\
(5 \mathrm{M})\end{array}$ \\
\hline $\begin{array}{l}\text { Myotis thysanodes } \\
\text { Fringed myotis }\end{array}$ & 0 & $\begin{array}{c}1 \\
(1 \mathrm{M})\end{array}$ & 0 & 0 & 0 & $\begin{array}{c}1 \\
(1 \mathrm{M})\end{array}$ \\
\hline $\begin{array}{l}\text { Myotis volans } \\
\text { Long-legged myotis }\end{array}$ & 0 & $\begin{array}{c}1 \\
(1 \mathrm{~F})\end{array}$ & $\begin{array}{c}15 \\
(5 \mathrm{~F}, 10 \mathrm{M})\end{array}$ & 0 & 0 & $\begin{array}{c}16 \\
(6 \mathrm{~F}, 10 \mathrm{M})\end{array}$ \\
\hline \multicolumn{7}{|l|}{ Other Species } \\
\hline $\begin{array}{l}\text { Eptesicus fuscus } \\
\text { Big brown bat }\end{array}$ & 0 & 0 & $\begin{array}{c}13 \\
(7 \mathrm{~F}, 6 \mathrm{M})\end{array}$ & 0 & $\begin{array}{c}1 \\
(1 \mathrm{~F})\end{array}$ & $\begin{array}{c}14 \\
(8 \mathrm{~F}, 6 \mathrm{M})\end{array}$ \\
\hline $\begin{array}{l}\text { Lasionycteris noctivagans } \\
\text { Silver-haired bat }\end{array}$ & 0 & 0 & $\begin{array}{c}1 \\
(1 \mathrm{M})\end{array}$ & 0 & 0 & $\begin{array}{c}1 \\
(1 \mathrm{M})\end{array}$ \\
\hline $\begin{array}{l}\text { Lasiurus cinereus } \\
\text { Hoary bat }\end{array}$ & $\begin{array}{c}1 \\
(1 \mathrm{~F})\end{array}$ & 0 & 0 & 0 & 0 & $\begin{array}{c}1 \\
(1 F)\end{array}$ \\
\hline $\begin{array}{l}\text { Myotis californicus } \\
\text { California myotis }\end{array}$ & 0 & 0 & 0 & 0 & $\begin{array}{c}4 \\
(3 \mathrm{~F}, 1 \mathrm{M})\end{array}$ & $\begin{array}{c}4 \\
(3 \mathrm{~F}, 1 \mathrm{M})\end{array}$ \\
\hline $\begin{array}{l}\text { Pipistrellus hesperus } \\
\text { Western pipistrelle }\end{array}$ & 0 & $\begin{array}{c}2 \\
(1 \mathrm{~F}, 1 \mathrm{M})\end{array}$ & 0 & 0 & $\stackrel{2}{(1 \mathrm{M}, 1 \mathrm{U})}$ & $\begin{array}{c}4 \\
(1 \mathrm{~F}, 2 \mathrm{M} \\
1 \mathrm{U})\end{array}$ \\
\hline $\begin{array}{l}\text { Tadarida brasiliensis } \\
\text { Mexican free-tailed bat }\end{array}$ & 0 & 0 & 0 & 0 & $\begin{array}{c}2 \\
(2 \mathrm{M})\end{array}$ & $\begin{array}{c}2 \\
(2 \mathrm{M})\end{array}$ \\
\hline Unknown species & 0 & 2 & 5 & 1 & 0 & 8 \\
\hline Total & 1 & 17 & 52 & 1 & 9 & 80 \\
\hline
\end{tabular}

The Mojave Desert portion of the NTS was sampled on August 18, 1998; March 29, 1999; and June 28, 1999. The southern route was modified in March and June to go past Well 5B Pond in Frenchman Flat. Yucca Flat was sampled on October 21, 1998; April 19, 1999; and June 29, 1999. This route was modified in April and June to sample along portions of Pahute Mesa Road and Tippipah Highway. Rainier Mesa was sampled on October 19, 1998; April 14, 1999; and 
July 12, 1999. This route was modified in April and July to sample along portions of East Mesa Road. Pahute/Buckboard Mesas were sampled on October 7, 1998; April 15, 1999; and July 14, 1999. In October and July, this route included a 2-mi $(1.3-\mathrm{km})$ portion of the U19a road whereas the route in April included a 2-mi portion of Dead Horse Flat Road past Pahute Pond.

Preliminary analysis of the call data show that no new bat species were recorded during the road surveys. The western pipistrelle (Pipistrellus hesperus) and California myotis appear to be the dominant species in the Mojave Desert and Transition Zone of the NTS and throughout Yucca Flat while the small-footed and long-legged myotis (Myotis volans) appear to be the dominant species in the Great Basin Desert portion of the NTS. Most of the bat activity detected occurred at water sources. Very few "commuting" bats were detected along the roadside.

Mine and Tunnel Anabat Surveys - Mines and tunnels are important or even critical habitats for some bat species. These man-made excavations can be used as day and night roosts and sites for maternity colonies and hibernacula. Anabat surveys were initiated at some of the historic mines and DOE-excavated tunnels on the NTS to determine their use by bats. The following mines and tunnels were sampled (Figure 9): Old Climax Mine adit (June 24), Mine Mountain adit and shafts (May 5 and 10), A Tunnel (April 13), B Tunnel (August 4), N Tunnel main entrance (August 11), and N Tunnel vent hole and main entrance (August 17). The Anabat II system was set up at each mine/tunnel just after sunset and bat calls were recorded for two to three hours.

Preliminary results indicate that four bat species of concern were detected at mine/tunnel entrances. These include the small-footed, long-legged, long-eared (Myotis evotis), and fringed (Myotis thysanodes) myotis. Two other bat species were also detected; California myotis and western pipistrelle.

Verification of Species-Specific Bat Calls - To date, over 4,600 files of bat calls have been recorded on the NTS. BN biologists have tentatively classified approximately half of these files by species. A contract was set up this FY with Mike O'Farrell of O'Farrell Biological Consulting to confirm these file classifications and to assist in the classification of the remaining files. Dr. O'Farrell is one of the leading experts in using the Anabat II system to study bats in North America. With Dr. O'Farrell's assistance, all files of recorded bat calls were classified by species and verified this FY. Next year, these verified Anabat call data will be combined with the mist-net capture data to better describe the distribution of bat species across sample locations on the NTS.

\section{Identifying Monitoring Parameters and Threshold Levels for Adaptive Management -}

Baseline data on the number of bats and bat species detected at selected sampling sites and road routes will continue to be collected next FY. A study design will be developed next year which will address how to monitor bat abundance and distribution over time on the NTS. This study design will identify monitoring parameters, sampling methods and frequencies, threshold levels for selected parameters, and adaptive management actions.

\subsection{Other Federally Protected/State-managed Species}

Wild horses (Equus caballus) occur on the NTS and ongoing monitoring of this species was conducted in FY 1999. Wild horses are protected on public lands under the Wild Free-Roaming 
Horse and Burro Act of 1971. This act calls for the management and protection of wild horses and burros in a manner that is designed to achieve and maintain a thriving natural ecological balance. Although the NTS is on land withdrawn from public use, DOE/NV is committed to this same management goal on the NTS. In 1997, DOE/NV signed a Five-Party Cooperative Agreement with Nellis Air Force Base (Nellis), FWS, BLM, and the State of Nevada Clearinghouse. The goal of the agreement is to enhance management of the natural resources within ecosystems on the Nellis Air Force Range (NAFR), the NTS, and the Desert National Wildlife Range. This agreement facilitates an ecosystem-based approach in the management of free-roaming animals with large home ranges, such as wild horses. Nellis allows the BLM to conduct periodic horse roundups and removals to ensure sustainable populations of wild horses and wildlife forage species on the NAFR, and BN conducts an annual horse census on the NTS.

Several birds of prey (raptors) occur and breed on the NTS which are not protected under the ESA and are not species of concern. These raptors, however, are protected by the federal government under the Migratory Bird Treaty Act and by the state of Nevada. Raptors include all vultures, hawks, kites, eagles, ospreys, falcons, and owls. Because these birds occupy high trophic levels of the food chain, they are regarded as sensitive indicators of ecosystem stability and health. Information on the number and distribution of raptor breeding sites on the NTS is lacking. Field studies were initiated last FY and continued this year to identify such sites to better protect them from impacts of NTS activities.

Mule deer (Odocoileus hemionus) are State-managed game which occur throughout the NTS. Their population numbers have not been censused since 1994. Because of the decline in horse numbers observed on the NTS over the last five years, BN re-initiated mule deer monitoring. Spotlighting surveys along roads were conducted to examine if the number of deer on the NTS have also decreased over the same period of time.

\subsubsection{Wild Horses}

The NTS horse population has not increased in size over time as on the NAFR, and it appears to be isolated from the NAFR population. In the past five years, a decline in horse numbers on the NTS has been observed. In FY 1999, BN biologists performed two sub-tasks related to horse monitoring:

C Annual horse abundance was estimated to monitor population stability.

C Horse sign were recorded along selected roads to better define the geographic range of horses on the NTS.

C Selected natural and man-made water sources were visited in the summer to determine their influence on horse distribution and movements and to determine the impact horses are having on NTS wetlands.

\subsubsection{Abundance Survey}

A total count of individual horses was taken to estimate horse abundance on the NTS. The count was conducted during eight nonconsecutive days between July and September. A standard road course on 
the NTS was driven to locate and identify horses (Figure 10). Individuals were identified by their unique physical features. The direct population count in FY 1999 was

31 individuals. Six adult horses (five males and one female) which were alive in FY 1998 were not observed. One male horse, which was not observed in 1998, was seen this year. A total of five foals were observed with their mares.

Since 1995, the feral horse population has declined 43 percent, from 54 to 31 individuals (these counts exclude foals) (Table 9). Of the 23 horses which have been classified as missing since 1995, 11 were males, 10 were females, and 2 were yearlings of unknown sex. No foals observed in 1995 through 1998 survived to yearlings. Natural processes (e.g., predation, emigration) may be likely causes of the observed population decline. Although some indirect evidence of predation on foals and adults has been observed (e.g., partially eaten carcasses), direct evidence is lacking.

Table 9. Number of horse individuals observed on the NTS by age class, gender (M=male; $F=f$ female), and year since 1995

\begin{tabular}{|c|c|c|c|c|c|c|c|c|c|c|}
\hline \multirow[t]{2}{*}{ Age Class } & \multicolumn{10}{|c|}{ Number of Individuals Observed } \\
\hline & \multicolumn{2}{|c|}{1995} & \multicolumn{2}{|c|}{1996} & \multicolumn{2}{|c|}{1997} & \multicolumn{2}{|c|}{1998} & \multicolumn{2}{|c|}{1999} \\
\hline $\begin{array}{l}\text { Foals } \\
\text { Yearlings }\end{array}$ & \multicolumn{2}{|c|}{1} & \multicolumn{2}{|c|}{1} & \multicolumn{2}{|c|}{3} & \multicolumn{2}{|c|}{8} & & \\
\hline Adults & $\mathbf{M}$ & $\mathbf{F}$ & $\mathbf{M}$ & $\mathbf{F}$ & $\mathbf{M}$ & $\mathbf{F}$ & $\mathbf{M}$ & $\mathbf{F}$ & $\mathbf{M}$ & $\mathbf{F}$ \\
\hline 2 Year Olds & 0 & 0 & 0 & 1 & 0 & 0 & 0 & 0 & 0 & 0 \\
\hline 3 Year Olds & 0 & 0 & 0 & 0 & 0 & 1 & 0 & 0 & 0 & 0 \\
\hline$>3$ Years Old & 22 & 29 & 21 & 24 & 19 & 20 & 16 & 21 & 11 & 20 \\
\hline $\begin{array}{c}\text { Total } \\
\text { (exluding foals) }\end{array}$ & \multicolumn{2}{|c|}{54} & \multicolumn{2}{|c|}{46} & \multicolumn{2}{|c|}{40} & \multicolumn{2}{|c|}{37} & \multicolumn{2}{|c|}{31} \\
\hline
\end{tabular}

\subsubsection{Annual Range Survey}

The annual population census of horses has routinely been conducted in the summer when horses are nearer to water sources and thus easier to find. These census surveys provide an adequate estimate of the summer range of horses on the NTS but are not useful for estimating their annual range. During FY 1999, selected roads were driven within and along the boundaries of the suspected annual horse range and all fresh sign (estimated to be $<1$ year old) located on and adjacent to the roads were recorded. Four days of effort were expended for the road surveys. Horse sign data collected during the road surveys and horse use at natural and man-made water sources indicate that the 1999 NTS horse range includes Kawich Canyon, Gold Meadows, northwest Yucca Flat, southwest foothills of the Eleana Range, and southeast Pahute Mesa (Figure 10). The annual horse range appears not to have changed from last year. 


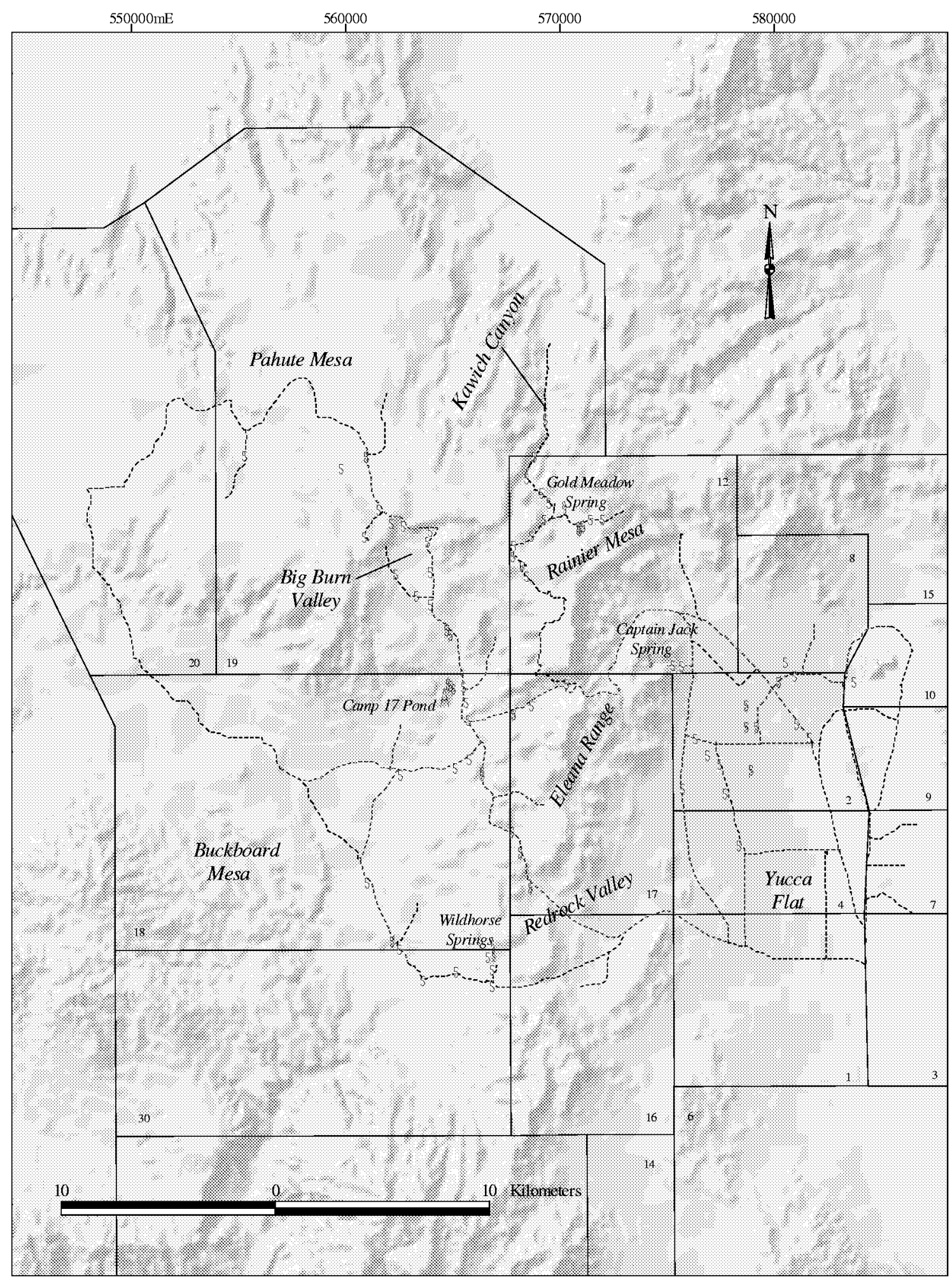

Figure 10. Feral horse sightings and horse sign observed on the NTS during FY 1999 


\subsubsection{Use of NTS Water Sources}

The NTS horse population appears dependent in the summer on several natural and man-made water sources in Areas 18, 12, and 30. Two wetlands in Area 30, Wild Horse and Little Wild Horse seeps, are located within the annual horse range and were used by horses in the spring and summer (Figure 10). Only two other natural water sources (Captain Jack Spring in Area 12, Gold Meadows Spring in Area 12) and one man-made pond (Camp 17 Pond in Area 18) were used by horses this summer, as in past years. Captain Jack Spring, Gold Meadows Spring, and Camp 17 Pond were used the most based on the presence and quantity of horse sign and trampled and grazed vegetation. The two wetlands in Area 30 were used heavily during the spring when their water flow was greater, but horse usage declined during June. In June, it appears that horses moved to higher elevations and were dependent on Camp 17 Pond for the remainder of the summer.

There are presently six man-made water sources within or on the edge of the annual horse range that were not used by horses in FY 1999. These are E-Tunnel Containment Ponds, Area 12 Sewage Ponds, and plastic-lined sumps at ER 19-1, ER 12-1, U10j, and U2gg (see Section 5.3.4; Figure 16). No horse sign have ever been found at the E-Tunnel Containment Ponds or the Area 12 Sewage Ponds.

\subsubsection{Identifying Population Size Threshold Level for Adaptive Management}

The horse monitoring task was evaluated this FY for its ability to determine if the RMP (DOE, 1998) goals are being met. Minimum threshold levels for the size of the NTS horse population should be identified, and when this threshold level is reached, it should trigger specific adaptive management actions. It has been noted for the past six years that horse numbers on the NTS have declined. BN biologists have conducted no field research to support the belief that the decline is due to natural causes versus the result of impacts from DOE activities. Some efforts should be made, however, to confirm this belief, particularly when horse numbers may be approaching the theoretical minimum viable population size (MVPS).

The MVPS is not known for the horse herds of the NTS. Next FY, a literature review will be conducted to identify an MVPS for feral horses in similar ecological settings which might be applied to the NTS herds. Also, draft study designs will be developed with the objectives of identifying all feasible direct and indirect causes of horse mortality on the NTS and quantifying reproduction, immigration, emigration, predation, and age-specific mortality. These field studies should be implemented when the MVPS is approached. The current horse monitoring study design will be modified next FY to include population threshold levels and a decision matrix of potential research, mitigation, and protective actions to be taken.

\subsubsection{Raptors}

\subsubsection{Ground Surveys for Nest Sites}

Including the burrowing owl (see Section 5.1.2.5), there are eight raptors (Table 10) which are known to breed on the NTS (Greger and Romney, 1994). Few records exist, however, of breeding raptors on the NTS or of their reproductive success, egg incubation periods, and 
fledging times (time when young leave the nest) (Hayward et al., 1963). Surveys to locate raptor nests and the number of breeding pairs of raptors began on the NTS in FY 1998 and were continued this FY.

Table 10. Raptor species that occur and breed on the NTS

\begin{tabular}{ll}
\hline Raptor Species & Common Name \\
\hline Aquila chrysaetos & Golden eagle \\
Asio otus & Long-eared owl \\
Buteo jamaicensis & Red-tailed hawk \\
Buteo swainsoni & Swainson's hawk \\
Falco mexicanus & Prairie falcon \\
Falco sparverius & American kestrel \\
Speotyto cuniculaia & Burrowing owl \\
Tyto alba & Barn owl \\
\hline \hline
\end{tabular}

From April through July, the following regions were surveyed on foot and by vehicle: Yucca Flat, Oak Spring Butte, Buckboard Mesa, Rainier Mesa, lower Stockade Wash, Shoshone Mountain, and the Tippipah Spring area. These regions included three new areas which had not been previously searched for raptor nests: a Joshua tree habitat in southeast Yucca Flat, a cliff site west of Tippipah Spring, and a cliff site in Stockade Wash. Ten of the twelve active nest sites found in 1998 (Figure 11; Table 11) were surveyed again this year.

Binoculars and spotting scopes were used to search cliff faces and Joshua trees. Soaring raptors, eliciting territorial defense calls, were also noted to determine if they were guarding or flying to and from a nest site. Areas around springs were also searched for raptor nests during monitoring of water sources (see Section 5.3.3). When nests were found, efforts were made to determine the number of young in the nest without disturbing the birds. All nest locations and nestling data were recorded and mapped. Nests containing young were periodically revisited to determine the status of nestlings.

Four new raptor nests were detected during ground searches this year (Figure 11; Table 11): a Joshua tree nest of a red-tailed hawk in southeast Yucca Flat in Area 3 (Nest ID A3-Y1), a red-tailed hawk cliff nest on the western edge of Buckboard Mesa in Area 18 (A18-C3), a red-tailed hawk nest on a microwave tower at N-Tunnel portal in Area 12 (A12-T1), and a golden eagle nest on an east-facing cliff about $1 \mathrm{~km}$ west of Tippipah Spring in Area 16 (A16-C1). A pair of red-tailed hawks was observed defending a cliff nest (A18-C3) which was about $500 \mathrm{~m}$ south of another cliff nest (A18-C2) that was used by red-tailed hawks last year.

Five active raptor nests were detected this year, whereas 12 were observed last year (Figure 11; Table 11). None of the Joshua tree nests and only one of the five cliff nests observed in FY 1998 was reused this year. The reused cliff nest was that of a golden eagle in Area 12 (A12-C1). Two eaglets were observed in this nest on May 5. However, only one eaglet was observed in the nest on May 25. Last year, one fledged eaglet was observed at this nest in late June. 


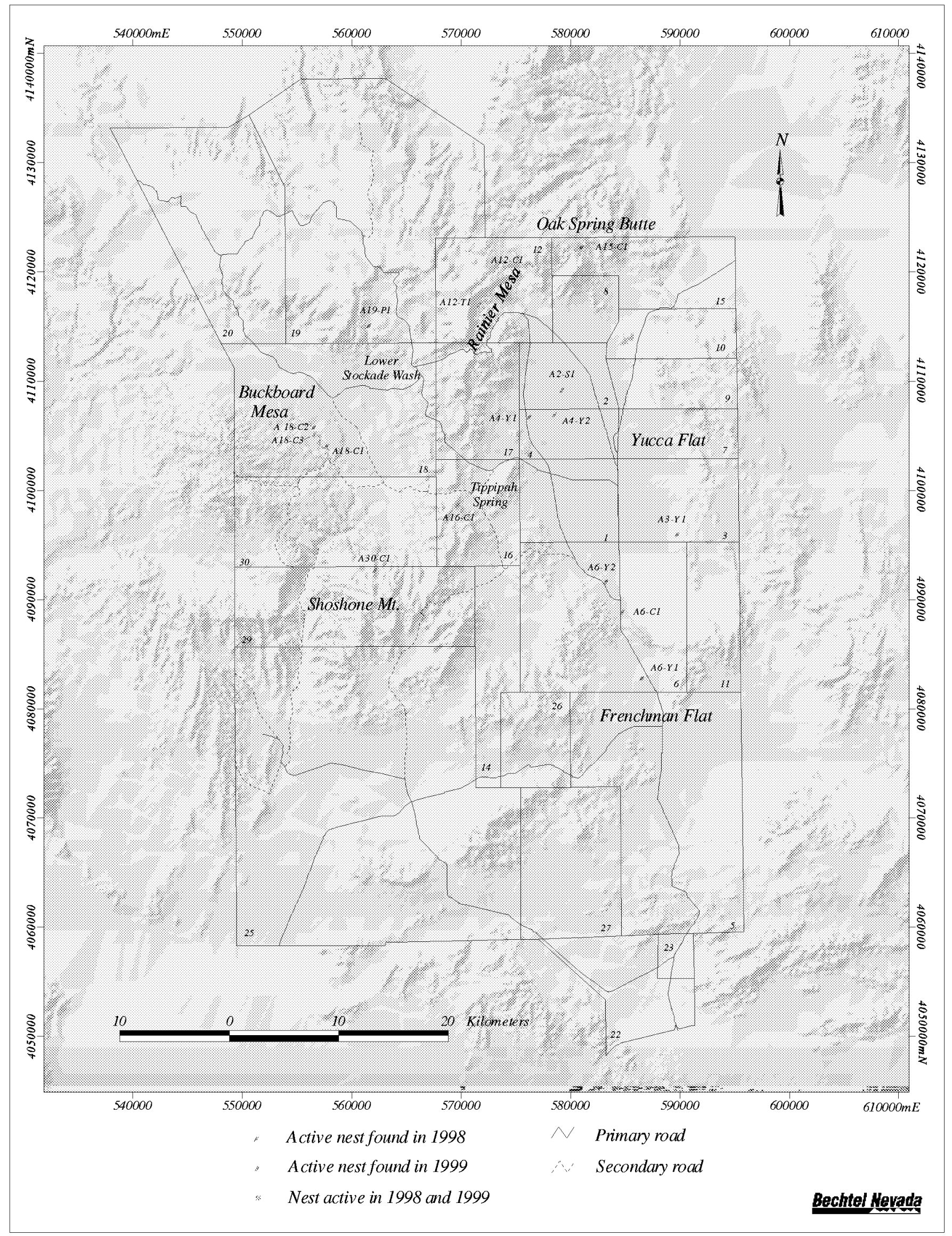

Figure 11. Locations of known raptor nests on the NTS during FY 1999 
Table 11. Status of known raptor nests found on the NTS

\begin{tabular}{|c|c|c|c|c|c|c|}
\hline \multirow[b]{2}{*}{ Nest ID } & \multirow[b]{2}{*}{ Species } & \multirow[b]{2}{*}{ Nest Type } & \multicolumn{2}{|c|}{ Nest Use Status } & \multicolumn{2}{|c|}{$\begin{array}{c}\text { Number of Young } \\
\text { Observed }\end{array}$} \\
\hline & & & FY 1998 & FY 1999 & FY 1998 & FY 1999 \\
\hline A19-P1 & American kestrel & Dead, hollow pine tree & Active & $\mathrm{ND}^{1}$ & $>1$ & $\mathrm{NA}^{2}$ \\
\hline $\mathrm{A} 2-\mathrm{S} 1$ & Barn owl & Manmade vertical shaft & Active & ND & 7 & NA \\
\hline $\mathrm{A} 12-\mathrm{Cl}$ & Golden eagle & Cliff stick nest & Active & Active & 1 & $\begin{array}{l}2 \text { on } 5 / 5 \\
1 \text { on } 5 / 25\end{array}$ \\
\hline $\mathrm{A} 16-\mathrm{C} 1$ & Golden eagle & Cliff stick nest & $\mathrm{UNK}^{3}$ & Active & NA & 1 on $5 / 11$ \\
\hline A18-C1 & Prairie falcon & Cliff eyrie & Active & Inactive & 5 & NA \\
\hline A4-Y1 & Red-tailed hawk & Joshua tree nest & Active & Inactive & 3 & NA \\
\hline A6-Y1 & Red-tailed hawk & Joshua tree nest & Active & Inactive & 2 & NA \\
\hline A6-Y2 & Red-tailed hawk & Joshua tree nest & Active & Inactive & 1 & NA \\
\hline $\mathrm{A} 6-\mathrm{C} 1$ & Red-tailed hawk & Cliff stick nest & Active & Inactive & 1 & NA \\
\hline A18-C2 & Red-tailed hawk & Cliff stick nest & Active & Inactive & ND & NA \\
\hline $\mathrm{A} 30-\mathrm{C} 1$ & Red-tailed hawk & Cliff stick nest & Active & Inactive & 2 & NA \\
\hline A15-C1 & Red-tailed hawk & Cliff stick nest & Active & Inactive & 1 & NA \\
\hline A3-Y1 & Red-tailed hawk & Joshua tree nest & UNK & Active & NA & $\begin{array}{c}2 \text { on } 5 / 19 \\
1 \text { dead on } \\
6 / 30\end{array}$ \\
\hline A18-C3 & Red-tailed hawk & Cliff stick nest & UNK & Active & NA & ND \\
\hline A12-T1 & Red-tailed hawk & Microwave tower nest & UNK & Active & NA & ND \\
\hline $\mathrm{A} 4-\mathrm{Y} 2$ & Swainson's hawk & Joshua tree nest & Active & Inactive & 2 & NA \\
\hline $\begin{array}{l}D-\text { Not } \\
A-N o t \\
\text { NK - Ur }\end{array}$ & $\begin{array}{l}\text { mined. } \\
\text { cable. }\end{array}$ & 999. & & & & \\
\hline
\end{tabular}

The number of active nests is an index of the number of breeding pairs on the NTS. The low number of breeding pairs (i.e., active nests) observed this year may be due to a reduced prey base of mourning doves. Last year, large flocks of doves (sometimes $>300$ ) were observed at springs and sumps, whereas this year they were noticeably absent (see Section 5.3.3). Breeding red-tailed hawks in 
Frenchman Flat were observed killing and consuming large numbers of doves last year. Lower numbers of doves on the NTS (and other prey species like small mammals and insects) may be the result of a relatively dry fall, winter, and spring this year.

These survey data continue to support the recommendation to avoid, whenever possible, the removal of Joshua trees within proposed project areas because they are known to provide an important structural component to the ecosystem. Also, elevated cliff-nesting sites for species such as golden eagles and red-tailed hawks should be left unaltered whenever possible because they may be used repeatedly year after year.

\subsubsection{Raptor Mortality}

At the Joshua tree raptor nest A3-Y1, two red-tailed hawk nestlings were observed on May 19 (Table 11), but the remains of one of the fledgling hawks was found dead at the base of the Joshua tree on June 30. It is assumed that the fledgling was killed by a predator.

In June of this year, an adult golden eagle was found dead in Yucca Flat in Area 1. It was found at the base of an overhead power line and had been electrocuted. It is not known if this eagle was one of the breeding pairs using nest A12-C1 and nest A16-C1 (Table 11). The golden eagle, with the largest wingspan of all the NTS raptors, is exposed to the highest risk of electrocution from active NTS power lines.

Wildlife observations, made opportunistically by BN biologists and other NTS workers, are maintained by $\mathrm{BN}$ biologists in a computerized database. Accounts of injured and dead animals are also usually reported to $\mathrm{BN}$ biologists and are stored in the same database. As part of the effort to monitor raptors on the NTS, a subset of this database will be designed next fiscal year to report all accounts of dead raptors over the past 10 years and their cause of death, if recorded.

\subsubsection{Identifying Monitoring Parameters and Threshold Levels for Adaptive Management}

Baseline data on the number of breeding pairs of raptors, active nests, and fledgling young will continue to be collected in subsequent years. Until more data is collected, it is premature to identify specific monitoring parameters and their threshold levels for raptor monitoring.

\subsubsection{Mule Deer}

Mule deer appear to be less abundant on the NTS during the last five years compared to approximately ten years ago. This is based on qualitative observations of animals and their sign at springs and ponds. This could be due to numerous factors including drought and/or a general reduction over the last decade in the numbers of permanent earthen water sources in deer habitat (there are six fewer pond locations in or adjacent to Pinus monophylla / Artemisia ssp. Woodland habitat). Low numbers of deer as available prey for mountain lions could also cause mountain lions to prey more on horses, 
resulting in the decline of horse numbers measured from 1994 - 1999. Spotlighting surveys were initiated this FY to examine trends of relative abundance of deer on the NTS.

Spotlighting surveys were conducted once over three consecutive nights (August 23-25). Two BN biologists drove a standard road course while shining spotlights and counting all deer observed along a $100-\mathrm{m}$ viewing region along each side of the road. Roads driven totaled $75 \mathrm{~km}$ in length and were located in the northern regions of the NTS on and adjacent to Pahute Mesa and Rainier Mesa. These methods were identical to those used during past deer spotlighting surveys.

A total of 12,8 , and 7 deer were observed during three consecutive nights, respectively. The mean sighting rate over the three nights was 1.2 deer $10 \mathrm{~km}(\mathrm{~s}=0.42)$. This mean sighting rate is lower than that observed during any one year from 1989-1994 (range $=2.1$ deer $10 \mathrm{~km}$ to $5.5 \mathrm{deer} / 10 \mathrm{~km}$ ). Two more sampling periods are planned for October and November 1999. Next FY, a mule deer monitoring plan will be developed which will identify sampling frequencies, threshold values for mean sighting rates, and adaptive management actions to be taken related to monitoring this species on the NTS.

\subsection{Wetlands and Wildlife Water Sources}

Natural wetlands and man-made water sources on the NTS provide unique habitats for mesic and aquatic plants and animals and attract a variety of other wildlife. Natural NTS wetlands may qualify as jurisdictional wetlands under the Clean Water Act (CWA). Characterization of these mesic habitats to determine their status under the CWA and periodic monitoring of their hydrologic and biotic parameters as components of the EMAC program which were started in

FY 1997. Periodic wetlands monitoring may help identify annual fluctuations in measured parameters that are natural and unrelated to DOE/NV activities. Also, if a spring classified as a jurisdictional wetland were to be unavoidably impacted by a DOE/NV project, mitigation for the loss of wetland habitat would be required under the CWA. Under these circumstances, wetland hydrology, habitat quality, and wildlife usage data collected at the impacted spring over several previous years can help to develop a viable mitigation plan and demonstrate successful wetland mitigation.

Man-made excavations constructed to contain water occur on the NTS and also attract wildlife. Along with natural water sources, these man-made sources can affect the movement patterns of some species (e.g., wild horses). However, they can also cause accidental wildlife mortalities from entrapment and drowning if not properly constructed or maintained. Quarterly visits to these water sources were conducted in FY 1999 to document wildlife use and mortality.

\subsubsection{Wetland Delineation of New NTS Natural Water Sources}

In FY 1998, BN biologists described five new wetland sites on the NTS (four new seeps and one manenhanced pond) which were previously undescribed (BN, 1998a; Figure 12; Table 12).

Photographs of three of these water sources (Rattlesnake, Wildhorse, and Little Wildhorse seeps) were included in last year's progress report (BN, 1998a). This year, photographs were taken of the other two sites, Pahute Mesa Pond (Figure 13) and Wahmonie Seep \#4 (Figures 14 and 15). 


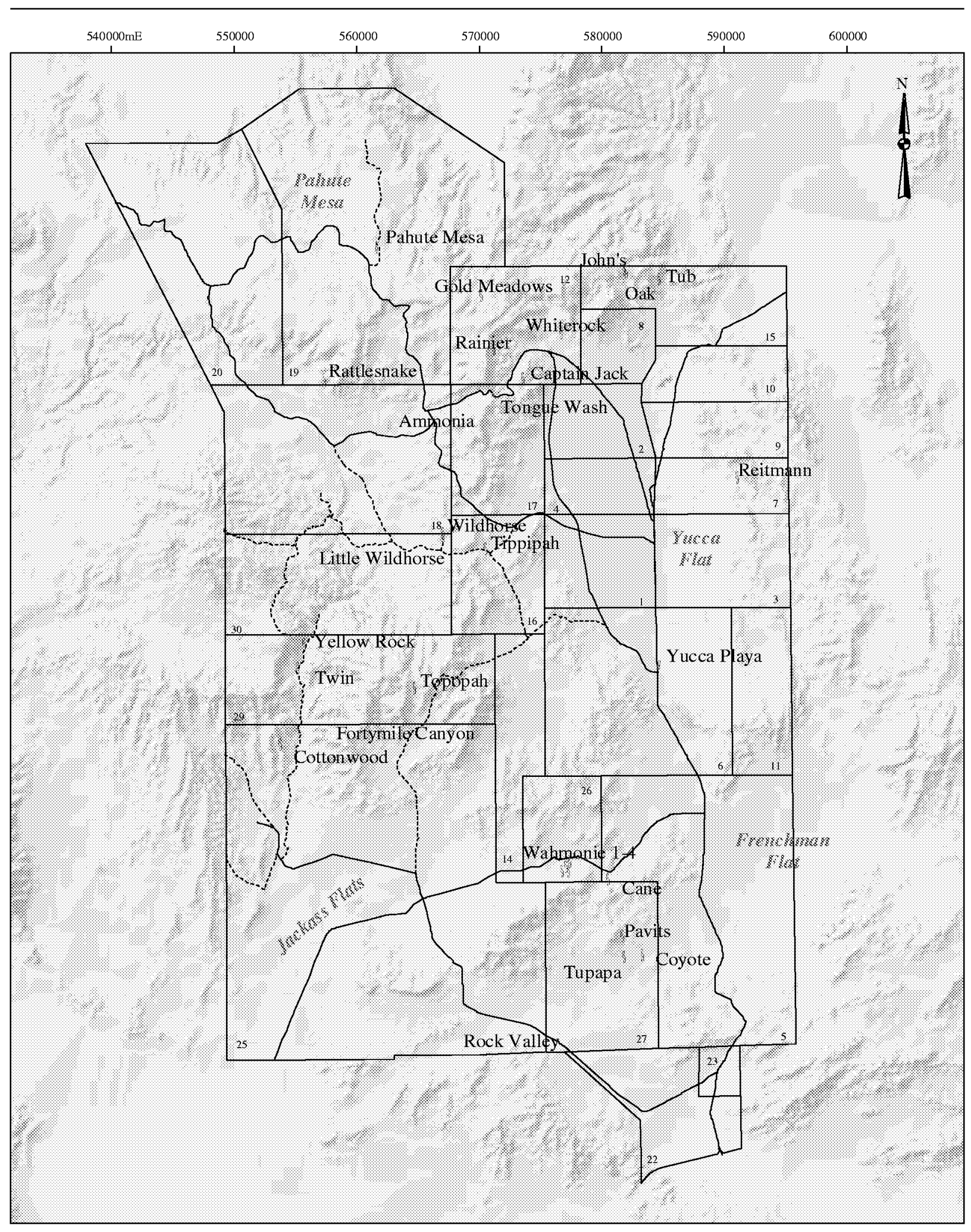

Figure 12. Natural water sources on the NTS 
Table 12. Findings on the jurisdictional wetland status of five new NTS water sources surveyed May 5, 1999

Presence of Wetland Indicators

\begin{tabular}{|c|c|c|c|c|}
\hline Water Source & Vegetation & Hydrology & Soils & $\begin{array}{c}\text { Jurisdictional } \\
\text { Status }\end{array}$ \\
\hline Little Wildhorse Seep & yes & yes & yes & yes \\
\hline Pahute Mesa Pond & $\mathrm{TBD}^{1}$ & TBD & TBD & no \\
\hline Rattlesnake Seep & no & yes & yes & no \\
\hline Wahmonie Seep \#4 & yes & yes & yes & yes \\
\hline Wildhorse Seep & yes & yes & yes & yes \\
\hline
\end{tabular}

${ }^{1} \mathrm{TBD}$ - to be determined, more site visits are required.

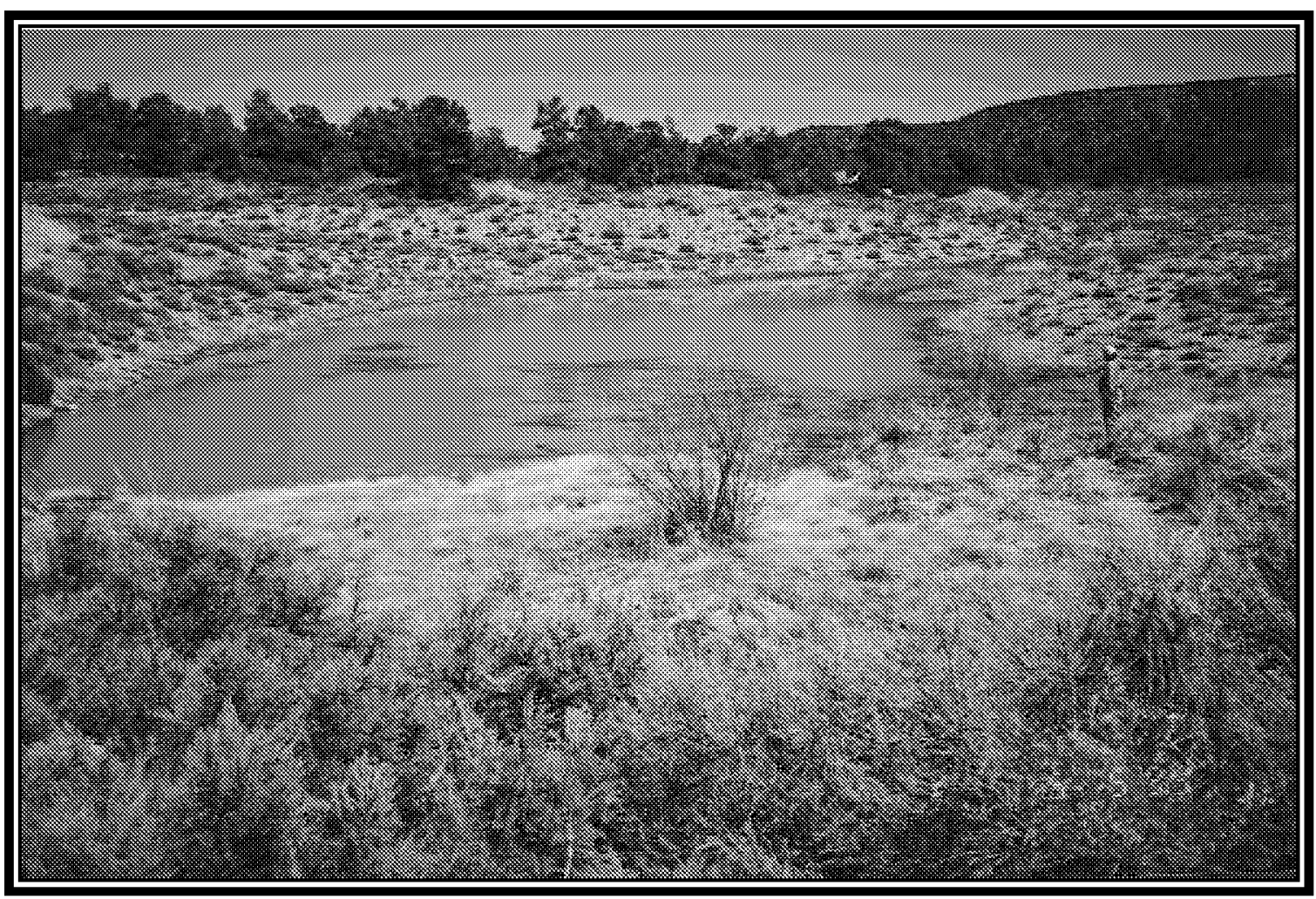

Figure 13. Pahute Mesa Pond wetland in Area 19 of the NTS (photo taken May 5, 1999) 


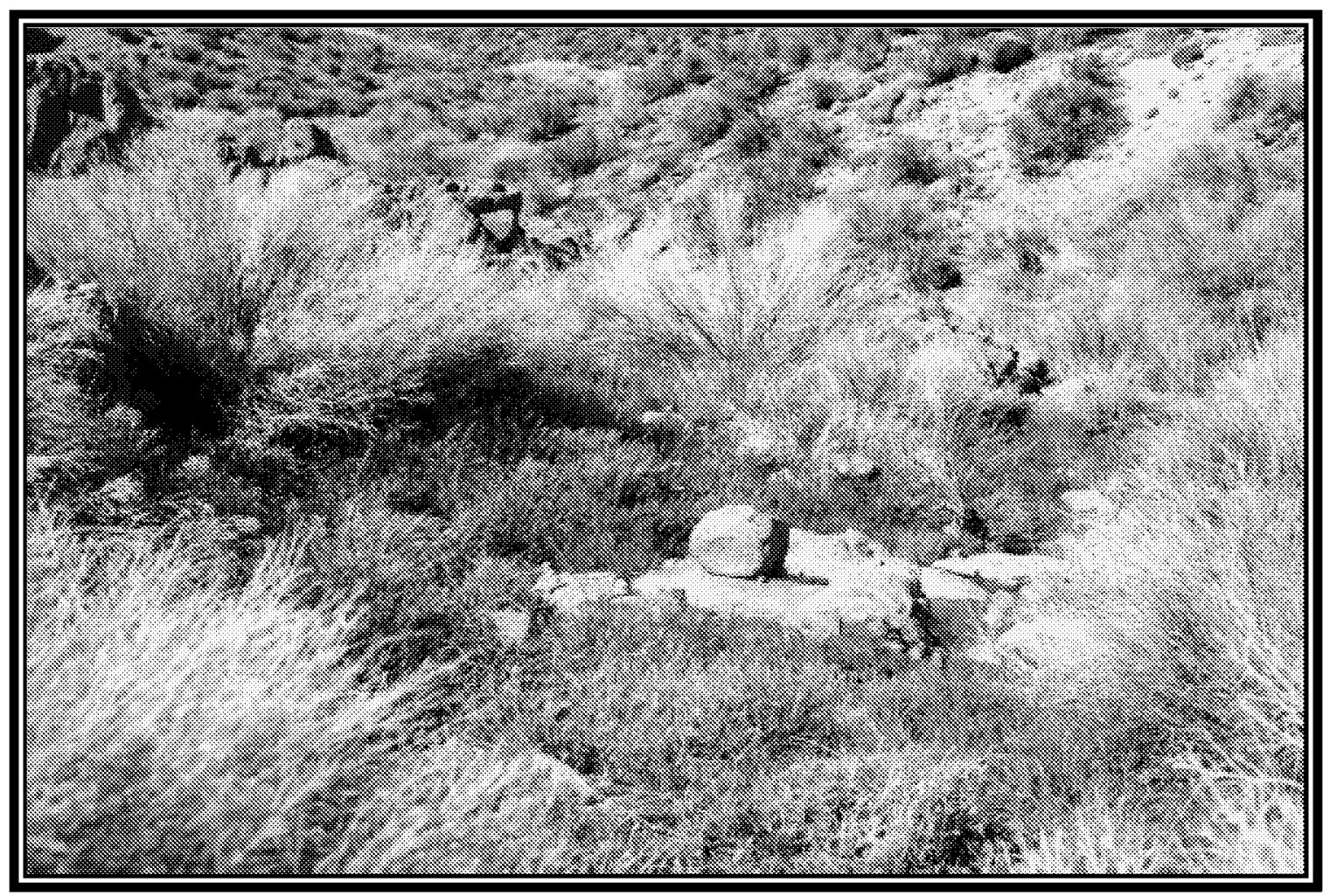

Figure 14. View of drainage at Wahmonie Seep \#4 wetland on the NTS (photo taken April 8, 1998)

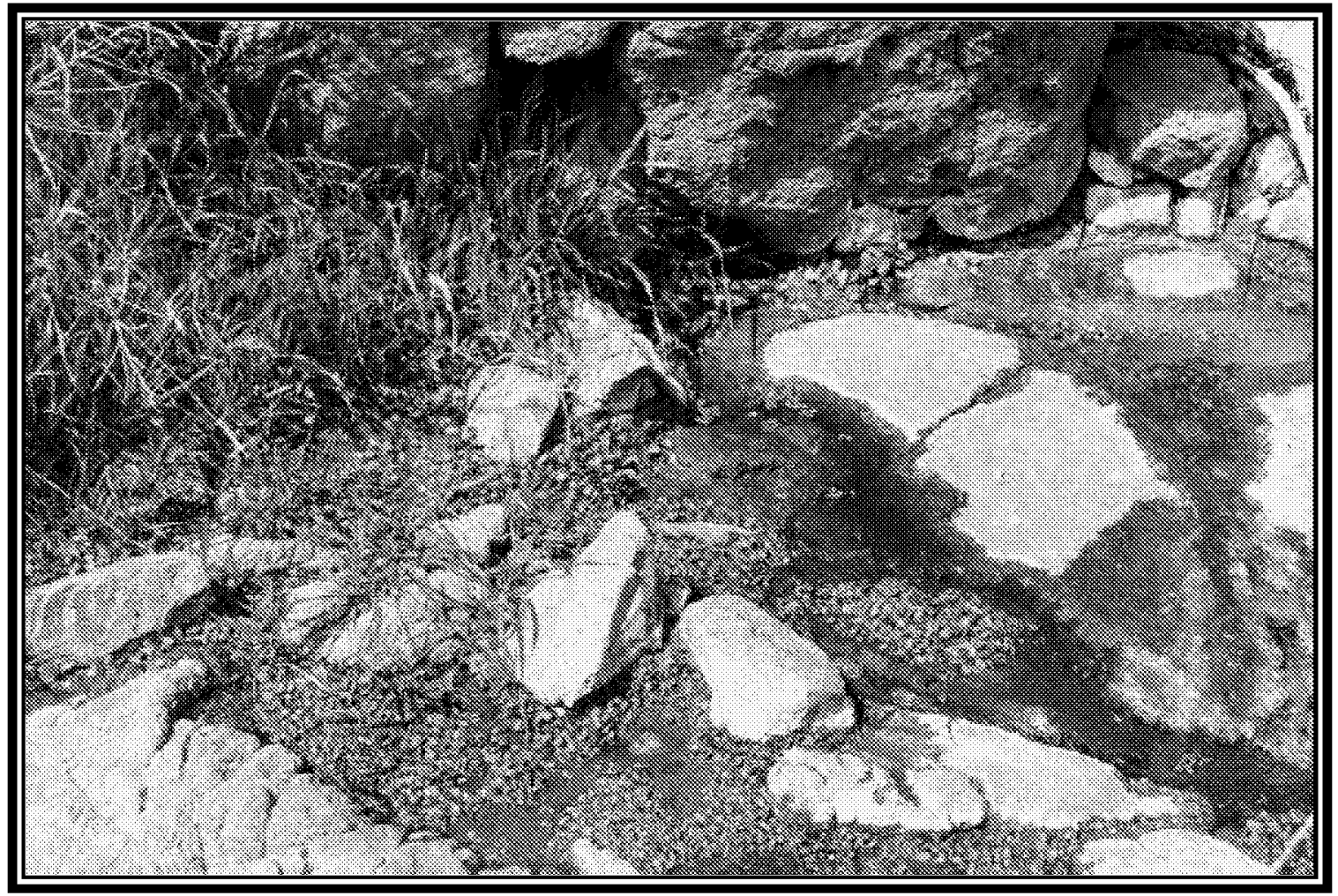

Figure 15. Closeup view of pool area at Wahmonie Seep \#4 (photo taken April 8, 1998) 
The man-enhanced water source, Pahute Mesa Pond, appears to be an historic borrow pit which catches surface runoff in large enough quantities and for long enough periods to sustain wetland vegetation.

The five new water sources were visited on May 5 to determine if they meet the criteria of jurisdictional wetlands. To be jurisdictional wetlands, they must have the following three field indicators: hydrophytic vegetation, wetland hydrology, and hydric soils. These field indicators have been measured and reported for the other 25 natural water sources of the NTS (Hansen et al., 1997). During the May survey, vegetated areas at Little Wildhorse Seep, Wahmonie Seep \#4, and Wildhorse Seep possessed all three field indicators of jurisdictional wetlands (Table 12). Pahute Mesa Pond and Rattlesnake Seep lacked dominance of hydrophytic vegetation. Vegetation conditions at Pahute Mesa Pond were not optimal in May for positive identification of plant species. Future visits to the site are needed to verify the vegetation field indicators.

These five water sources will continue to be monitored for the next two years to determine variations in site vegetation and hydrology. Hydrology appears to fluctuate depending on the preceding winter and spring's precipitation. Continued monitoring will determine the areal extent of surface water and the specific time of year during the growing season when water persists on the surface. Once the hydrology and vegetation of these sites have been fully characterized in FY 2000, a supplement to the previous wetlands report (Hansen et al., 1997) will be prepared.

\subsubsection{Development of a Routine Wetland Monitoring Plan}

After reviewing data collected for the wetlands report (Hansen et al., 1997), and data which has historically been collected during quarterly spring monitoring (BN, 1998a), a need was identified to revise current data collection procedures and to develop a Routine Wetland Monitoring Plan. The plan will identify those NTS wetlands which will be monitored and the data parameters that will be collected and reported annually. BN biologists will consult with NTS hydrologists to determine which, if any, water chemistry measures should be collected. The selection of wetland sites and data parameters will be based on the following key objectives of the new plan:

C Determine the jurisdictional status of new wetland areas.

C Identify wetland and wildlife changes that may reflect direct impacts of DOE activities.

C Assess water flow rates and changes in wetland area that can be correlated with changes in NTS climate and global warming.

C Monitor wetlands with highest potential for impacts due to their location, accessibility, and past history.

C Identify wetland and wildlife changes that may reflect on the health of ecosystems on the NTS.

These objectives, as well as detailed descriptions of data collection methods, schedule, analysis, and adaptive management actions will be identified in the new Routine Wetland Monitoring Plan. The plan will be developed using the EPA's Data Quality Objectives process (EPA, 1994) and is scheduled for completion by the end of FY 2000. 


\subsubsection{Wetland Monitoring}

Monitoring of selected NTS wetlands was continued this FY to characterize seasonal baselines and trends in physical and biological parameters. A total of 18 wetlands was visited at least once during the year to record the presence/absence of land disturbance, water flow rates, and surface area of standing water (Table 13). Wildlife use data collected at the majority of these water sources are shown in Table 14.

\subsubsection{Monitoring of Man-Made Water Sources}

BN biologists conducted quarterly monitoring of man-made water sources. These sources, located throughout the NTS (Figure 16), include 35 plastic-lined sumps, 39 sewage treatment ponds, 13 unlined well ponds, and 4 radioactive containment ponds. Several ponds or sumps are located next to each other at the same project site. Many NTS animals rely on these man-made structures as sources of free water. Wildlife and migratory birds may drown in steep-sided or plastic-lined sumps as a result of entrapment, or ingest contaminants in drill-fluid sumps or evaporative ponds. Mitigation measures, required under the Mitigation Action Plan for the Final Environmental Impact Statement for the Nevada Test Site and Off-Site Locations in the State of Nevada (DOE, 1996), include placing flag lines over contaminated water sources to repel birds or fencing or covering them. Ponds are monitored to assess their use by wildlife and to develop and implement mitigation measures to prevent them from causing significant harm to wildlife.

Man-made water sources were visited during four quarterly sampling periods: November, February, May, and August. At each site, a BN biologist recorded the presence or absence of standing water and the presence of animals or their sign around the water source. At plastic-lined sumps, the biologist also estimated the surface area of water and the presence, absence, and condition of fences and flag lines. Some type of ramps or ladders, which allow animals to escape if they fall in, have also been installed at many plastic-lined sumps, and the presence, absence, and condition of these structures were also noted. All dead animals (or any remains of an animal) in or adjacent to a man-made water source were recorded. All survey observations were summarized in quarterly reports (BN, 1998e; 1999g; q; v).

During FY 1999, use of unlined sumps and ponds by waterfowl (ducks, shorebirds) and mammals, such as coyotes and deer, was common. Only one man-made pond (Camp 17 Pond in Area 18) was used this year by wild horses. The fences installed around the plastic-lined sumps do not exclude coyotes or deer as their tracks were observed commonly inside many of the fences. Birds were observed much less at the plastic-lined sumps compared to the unlined ponds.

Four coyotes drowned in sump \#3, a plastic-lined sump at ER-20-6 in Area 20. Two dead coyotes were found in the sump during November 1998, and another two during September 1999. One deer was also found dead in sump \# 4, also located at ER-20-6, during February 1999.

Sump \# 3 is particularly dangerous to animals because it is commonly nearly full and there are no ramps extending above the waterline which can be used by trapped animals. Recommendations to install a sediment ramp in one corner of this sump and lowering the water level 4-5 ft in depth were made in the quarterly reports. 
Table 13. Seasonal data from selected natural water sources on the NTS collected during FY 1999

\begin{tabular}{|c|c|c|c|c|}
\hline Water Source & Date & $\begin{array}{l}\text { Surface Area } \\
\text { of Water }\left(\mathbf{m}^{2}\right)^{a}\end{array}$ & $\begin{array}{l}\text { Surface Flow } \\
\text { Rate (L/Min) }\end{array}$ & Disturbance at Spring \\
\hline Cane Spring & $10 / 22$ & 10 & 2.7 & None \\
\hline Cane Spring & $1 / 20$ & 125 & 3 & Soil cave-in into cave pool \\
\hline Cane Spring & $4 / 15$ & 56 & 2.3 & None \\
\hline Captain Jack Spring & $10 / 29$ & 18 & 2.4 & Horse grazing/trampled vegetation \\
\hline Captain Jack Spring & $2 / 9$ & 15 & 2.1 & Horse grazing/trampled vegetation \\
\hline Coyote Spring & $4 / 14$ & 1 & 0 & None \\
\hline Cottonwood Spring & $5 / 12$ & 2 & 0 & None \\
\hline Gold Meadows Spring & $10 / 20$ & 200 & $\mathrm{NM}^{\mathrm{c}}$ & Horse grazing/trampled vegetation \\
\hline Gold Meadows Spring & $1 / 21$ & 100 & NM & Horse grazing/trampled vegetation \\
\hline Gold Meadows Spring & $7 / 26$ & 0 & $\mathrm{NM}$ & Horse grazing/trampled vegetation \\
\hline Little Wildhorse Seep & $4 / 21$ & 0 & 0 & Horse grazing/trampled vegetation \\
\hline Little Wildhorse Seep & $5 / 5$ & 2 & $\mathrm{NM}$ & Horse grazing/trampled vegetation \\
\hline Pahute Mesa Pond & $5 / 5$ & 2,275 & NM & None \\
\hline Rattlesnake Seep & $5 / 5$ & 3 & $\mathrm{NM}$ & None \\
\hline Reitmann Seep & $10 / 29$ & 1.5 & 0.04 & None \\
\hline Reitmann Seep & $1 / 26$ & 1.5 & 0.05 & None \\
\hline Tippipah Spring & $10 / 8$ & 295 & 6 & None \\
\hline Tippipah Spring & $1 / 13$ & 260 & 5.4 & None \\
\hline Tippipah Spring & $4 / 5$ & 380 & 3.6 & None \\
\hline Topopah Spring & $10 / 22$ & 28 & 0.8 & None \\
\hline Topopah Spring & $2 / 4$ & 36 & 0.7 & None \\
\hline Topopah Spring & $5 / 3$ & 69 & 0.28 & None \\
\hline Wahmonie Seep No. 1 & $4 / 1$ & 30 & 3.6 & None \\
\hline Wahmonie Seep No. 2 & $4 / 1$ & 4 & $\mathrm{NM}$ & None \\
\hline Wahmonie Seep No. 3 & $4 / 1$ & 0 & 0 & None \\
\hline Wahmonie Seep No. 4 & $4 / 1$ & 35 & $\mathrm{NM}$ & None \\
\hline Whiterock Spring & $10 / 20$ & 6 & 2.8 & None \\
\hline Whiterock Spring & $1 / 14$ & 175 & 1.9 & None \\
\hline Wildhorse Seep & $4 / 21$ & 0 & 0 & Horse grazing/trampled vegetation \\
\hline Wildhorse Seep & $5 / 5$ & 2 & $\mathrm{NM}$ & Horse grazing/trampled vegetation \\
\hline Yucca Playa Pond & $10 / 8$ & 0 & 0 & None \\
\hline Yucca Playa Pond & $1 / 20$ & 23,000 & NM & None \\
\hline
\end{tabular}


Table 14. Seasonal wildlife use at selected springs on the NTS during FY 1999. $P=$ species present, inferred from sign

\begin{tabular}{|c|c|c|c|c|c|c|c|c|c|c|c|c|c|}
\hline Wildlife Observed & & 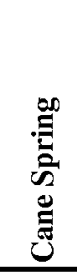 & & & & 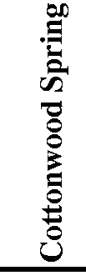 & 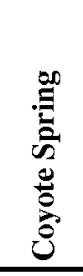 & & 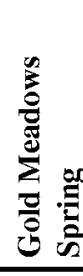 & & & & 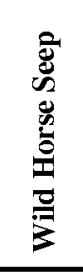 \\
\hline Mammals & $10 / 22$ & $1 / 20$ & $4 / 15$ & $10 / 2$ & $2 / 9$ & $5 / 12$ & $4 / 14$ & $10 / 20$ & $1 / 21$ & $7 / 20$ & $10 / 29$ & $1 / 26$ & $4 / 21$ \\
\hline $\begin{array}{l}\text { Coyote (Canus latrans) } \\
\text { Feral horse (Equus caballus) } \\
\text { Mule deer (Odocoileus hemionus) } \\
\text { Mountain lion (Felis concolor) } \\
\text { Birds }\end{array}$ & $\begin{array}{l}\mathbf{P} \\
\mathbf{P}\end{array}$ & $\begin{array}{l}\mathbf{P} \\
\mathbf{P}\end{array}$ & $\mathbf{P}$ & $\begin{array}{l}\mathbf{P} \\
\mathbf{P}\end{array}$ & & & $\mathbf{P}$ & $\mathbf{P}$ & $\mathbf{P}$ & $\mathbf{P}$ & $\mathbf{P}$ & $\mathbf{P}$ & $\begin{array}{l}\mathbf{P} \\
\mathbf{P}\end{array}$ \\
\hline $\begin{array}{l}\text { Black-throated sparrow (Amphispiza bilineata) } \\
\text { Brewer's sparrow (Spizella breweri) } \\
\text { Chukar (Alectoris chukar) } \\
\text { Gambel's quail (Calipepla gambelii) } \\
\text { Green-winged teal (Anas creeca) } \\
\text { Horned lark (Eremophila alpestris) } \\
\text { House finch (Carpodacus mexicanus) } \\
\text { Loggerhead shrike (Lanius ludovicianus) } \\
\text { Long-eared owl (Asio otus) } \\
\text { Northern harrier (Circus cyaneus) } \\
\text { Oregon junco (Junco hyemalis) } \\
\text { Rock wren (Salpinctes obsoletus) } \\
\text { Red-tailed hawk (Buteo jamaicensis) } \\
\text { Sage sparrow (Amhispiza bellii) } \\
\text { Say's phoebe (Saya saya) } \\
\text { White-crowned sparrow (Zonotrichia leucophyrs) }\end{array}$ & $\begin{array}{c}\mathbf{P} \\
>\mathbf{2 0}\end{array}$ & $\begin{array}{r}1 \\
6 \\
6 \\
4 \\
1 \\
>40\end{array}$ & $\begin{array}{c}>10 \\
1 \\
10\end{array}$ & & & 3 & $>20$ & $\begin{array}{l}>20 \\
>15\end{array}$ & & & & & \\
\hline
\end{tabular}




\begin{tabular}{|c|c|c|c|c|c|c|c|c|c|c|c|c|c|}
\hline Wildlife Observed & 总 & & 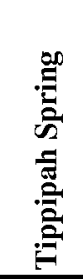 & & & 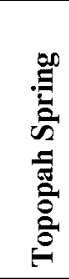 & & 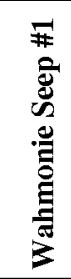 & 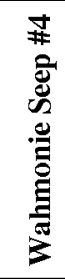 & \multicolumn{2}{|c|}{ 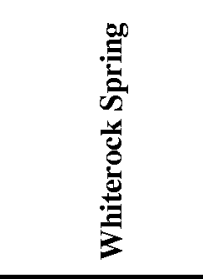 } & \multicolumn{2}{|c|}{  } \\
\hline Mammals & $4 / 21$ & $10 / 8$ & $1 / 13$ & $4 / 5$ & $10 / 22$ & $2 / 4$ & $5 / 3$ & $4 / 1$ & $4 / 1$ & $10 / 20$ & $1 / 14$ & $10 / 8$ & $1 / 20$ \\
\hline $\begin{array}{l}\text { Coyote (Canus latrans) } \\
\text { Feral horse (Equus caballus) } \\
\text { Mule deer (Odocoileus hemionus) } \\
\text { Mountain lion (Felis concolor) } \\
\text { Birds }\end{array}$ & $\begin{array}{l}\mathbf{P} \\
\mathbf{P} \\
\mathbf{P}\end{array}$ & $\mathbf{P}$ & $\mathbf{P}$ & $\mathbf{P}$ & & & $\mathbf{P}$ & $\mathbf{P}$ & $\mathbf{P}$ & $\mathbf{P}$ & $\mathbf{P}$ & $\mathbf{P}$ & $\mathbf{P}$ \\
\hline $\begin{array}{l}\text { Black-throated sparrow (Amphispiza bilineata) } \\
\text { Brewer's sparrow (Spizella breweri) } \\
\text { Chukar (Alectoris chukar) } \\
\text { Gambel's quail (Calipepla gambelii) } \\
\text { Green-winged teal (Anas creeca) } \\
\text { Horned lark (Eremophila alpestris) } \\
\text { House finch (Carpodacus mexicanus) } \\
\text { Loggerhead shrike (Lanius ludovicianus) } \\
\text { Long-eared owl (Asio otus) } \\
\text { Northern harrier (Circus cyaneus) } \\
\text { Oregon junco (Junco hyemalis) } \\
\text { Rock wren (Salpinctes obsoletus) } \\
\text { Red-tailed hawk (Buteo jamaicensis) } \\
\text { Sage sparrow (Amhispiza bellii) } \\
\text { Say's phoebe (Saya saya) } \\
\text { White-crowned sparrow (Zonotrichia leucophyrs) }\end{array}$ & 1 & $>40$ & $\begin{array}{l}>20 \\
>10 \\
>20\end{array}$ & $>15$ & $>60$ & $\mathbf{P}$ & $>\mathbf{2 0}$ & 12 & & $>50$ & $>2$ & 10 & $\begin{array}{r}>50 \\
1\end{array}$ \\
\hline
\end{tabular}




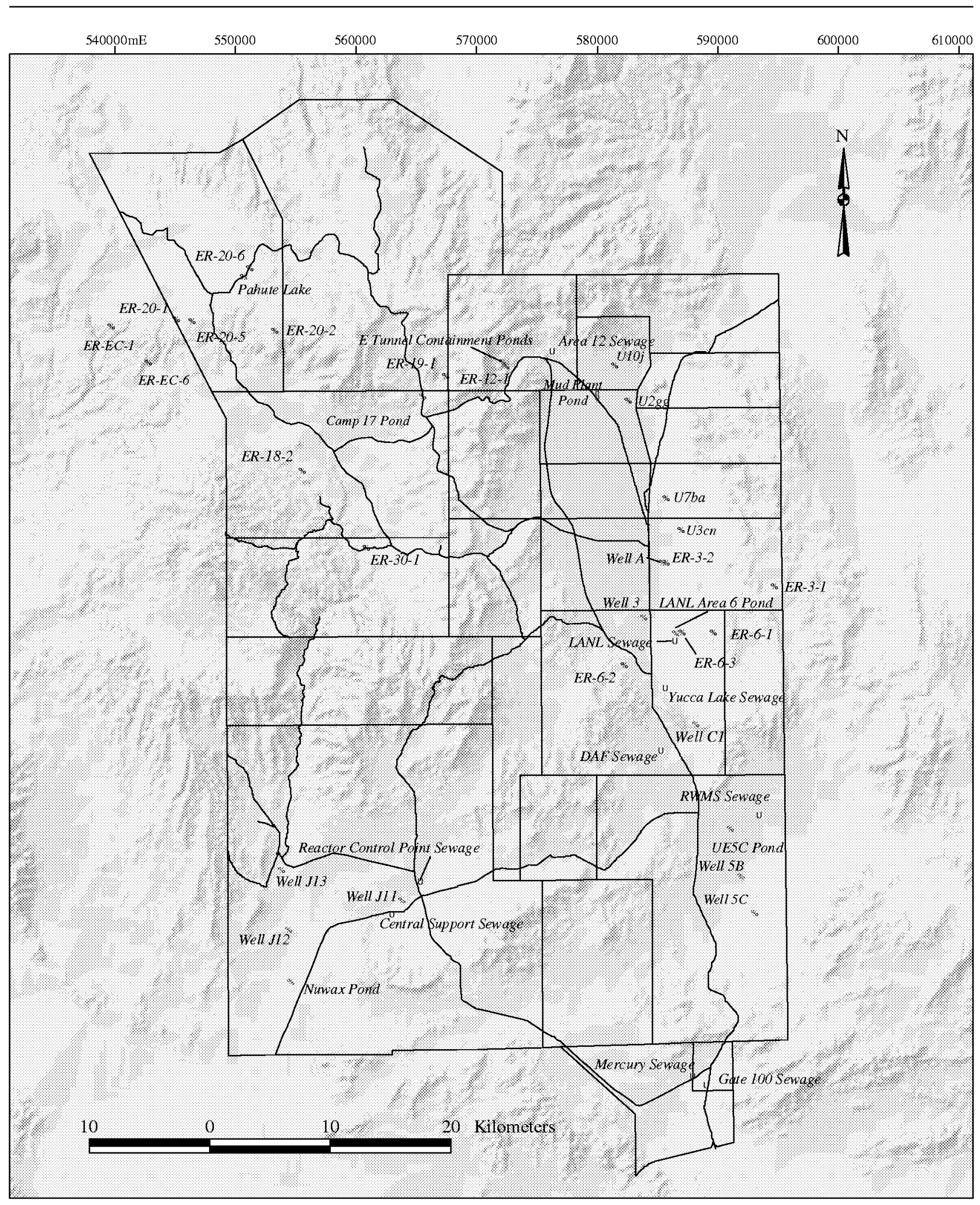

Figure 16. Man-made water sources monitored for wildlife use and mortality on the NTS during FY 1999 


\subsection{MONITORING OF THE HAZMAT SPILL CENTER}

\subsection{Task Description}

Biological monitoring at the HAZMAT Spill Center on the playa of Frenchman Lake in Area 5 is required for certain types of chemicals under the center's programmatic Environmental Assessment. These chemicals have either not been tested before, have not been tested in large quantities, or have uncertain modeling predictions of downwind air concentrations. In addition, ESHD has requested that BN monitor (downwind) any test which may impact plants or animals off the playa.

A document entitled Biological Monitoring Plan for Hazardous Materials Testing at the Liquefied Gaseous Fuels Spill Test Facility on the Nevada Test Site was prepared in FY 1996 (BN, 1996).

It describes how field surveys will be conducted to determine test impacts on plants and animals and to verify that the spill program complies with pertinent state and federal environmental protection legislation. The design of the monitoring plan calls for the establishment of three control transects and three treatment transects at three distances from the chemical release point which have similar environmental and vegetational characteristics. BN biologists are tasked to review spill test plans to determine if field monitoring along the treatment transects is required for each test as per the monitoring plan criteria. All test-specific field monitoring is funded through the HAZMAT Spill Center.

\subsection{Task Progress Summary}

BN reviewed chemical spill test plans for six experiments: (1) ORCA which tested ten different chemicals, (2) Chemical Agent Dual Detection Identification Experiment using three chemicals, (3) Remote Sensor Test Range Engineering Checkouts using two chemicals, (4) Off-gas Tests for Inhibited Red Fuming Nitric Acid, (5) Osprey I using five chemicals, and (6) Frostproof. The latter test was not at the HAZMAT Spill Center but was a stream fate study along the Cambric Ditch in Frenchman Flat. Letters documenting the first five reviews were submitted to ESHD on November 30 and December 2, 1998 and April 5, April 22, and April 22, 1999, respectively

(BN, 1998b; d; 1999k; n; o). Comments on the Frostproof test were provided in a meeting held on August 4, 1999.

Biota monitoring was not conducted for any of the chemical tests at the HAZMAT Spill Center during FY 1999. No baseline monitoring was conducted at established control-treatment transects near the HAZMAT Spill Center due to insufficient funding.

In the spring, BN biologists accompanied the BN and DOE/NV managers of the HAZMAT Spill Center on a tour of the facility given to FWS personnel. The eastern boundary of the NTS at Frenchman Flat is adjacent to the Desert National Wildlife Refuge (DNWR) which is managed by the FWS. Implementation of the monitoring plan is meant to ensure that harmful chemicals are not released onto DNWR land and that biota of the DNWR are not adversely affected by facility activities. 
THIS PAGE IS INTENTIONALLY LEFT BLANK 


\subsection{LITERATURE CITED}

Alcorn, J. R., 1988. The Birds of Nevada. Fairview West Publishing, Fallon, NV.

Anderson, D. C., 1998. Distribution of Clokey's Eggvetch (Astragalus oophorus var. clokeyanus) on the Nevada Test Site. DOE/NV/11718--262, Bechtel Nevada, Inc., Las Vegas, NV, December 1998.

Anderson, M., P. Bourgeron, M. T. Bryer, R. Crawford, L. Engelking, D. Faber-Langendoen, M. Gallyoun, K. Goodin, D. H. Grossman, S. Landall, K. Metzler, K. D. Patterson, M. Pyne, M. Reid, L. Sneddon, and A. S. Weakley, 1998. International Classification of Ecological Communities: Terrestrial Vegetation of the United States. Volume II. The National Vegetation Classification System: List of types. The Nature Conservancy, Arlington, VA.

Beatley, J. C., 1976. Vascular Plants of the Nevada Test Site and Central-Southern Nevada: Ecologic and Geologic Distributions. Technical Information Center, Office of Technical Information, Energy Research and Development Administration.

Beatley, J. C., 1979. Shrub and Tree Data for Plant Associations Across the Mojave/Great Basin Desert Transition of the Nevada Test Site, 1963-1975. DOE/EV/2307-15, U.S. Department of Energy, March 1979.

Benson, L., 1977. The Cacti of Arizona. The University of Arizona Press, Tuscon, AZ.

Berry, K. H., and L. L. Nicholson, 1984. The distribution and density of desert tortoise populations in California in the 1970s. Pages 26-60. In: K. H. Berry (ed.), The Status of the Desert Tortoise (Gopherus agassizii) in the United States. Desert Tortoise Council Report to U.S. Fish and Wildlife Service on Order No. 11310-0083-81. Portland, OR.

Blomquist, K. W., T. A. Lindemann, G. E. Lyon, D. C. Steen, C. A. Wills, S. A. Flick, and W. K. Ostler, 1995. Current Distribution, Habitat, and Status of Category 2 Candidate Plant Species on and Near the U.S. Department of Energy's Nevada Test Site. EGG 11265-1149. EG\&G Energy Measurements, Las Vegas, NV, December 1995.

BN (Bechtel Nevada), 1996. Biological Monitoring Plan for Hazardous Materials Testing at the Liquefied Gaseous Fuels Spill Test Facility on the Nevada Test Site. Submitted to U.S. Department of Energy, Nevada Operations Office, Letter from J. R. Kannard to R. C. Furlow, Correspondence No. E100-JRK-96-004, January 25, 1996.

- 1998a. Ecological Monitoring and Compliance Program Fiscal Year 1998 Report. DOE/NV/11718-255, Bechtel Nevada, Las Vegas, NV, October 1998.

, 1998b. Review of Orca Test Plan - Safety Assessment Document. Submitted to U.S. Department of Energy, Nevada Operations Office, Letter from W. K. Ostler to R. C. Furlow, Correspondence No. 2150-WO-99-0006, November 30, 1998. 
1998c. Biological Survey Report for Access Road for Fiberoptic Cable Installation (\#99-01). BN Interoffice Memorandum from C. A. Wills to C. Threats, Correspondence No. 2150-WO-99-0007, December 1, 1998.

1998d. Review of the Chemical Agent Dual Detection Identification Experiment (CADDIE) Test Plan - Safety Assessment Document. Submitted to U.S. Department of Energy, Nevada Operations Office, Letter from W. K. Ostler to R. C. Furlow, Correspondence No. 2150-WO-99-0009, December 2, 1998.

, 1998e. First Quarter Fiscal Year 1999 Monitoring of Manmade Water Sources on the Nevada Test Site. Submitted to U.S. Department of Energy, Nevada Operations Office, Letter from W. K. Ostler to R. C. Furlow, Correspondence Number 2150-WO-99-0011, December 16, 1998.

, 1998f. Biological Survey Report for Eight-Mile Segment of Jackass Flats to Mercury Fiberoptic Cable Route (\#98-03). BN Interoffice Memorandum from C. A. Wills to C. Threats, Correspondence No. 2150-WO-99-0012, December 30, 1998.

- 1999a. U.S. Department of Energy, Nevada Operations Office Annual Report of Actions Taken Under Authorization of the Biological Opinion on Nevada Test Site Activities (File No. 1-5-96-F-33) January 1, 1998 through December 31, 1998. Submitted to U.S. Department of Energy, Nevada Operations Office, Letter from

W. K. Ostler to R. C. Furlow, Correspondence No. 2150-WO-99-013, January 11, 1999. 1999b. Biological Survey Report for 11.4-Mile Segment of Jackass Flats to Mercury Fiber-optic Cable Route (\#99-03b). BN Interoffice Memorandum from C. A. Wills to C. Threats, Correspondence No. 2150-WKO-99-0016, January 21, 1999.

- 1999c. Biological Survey Report for U1a Complex Upgrades Project - U1h Shaft (\#99-04). BN Interoffice Memorandum from C. A. Wills to D. Rees, Correspondence No. 2154-CW-99-0017, January 21, 1999.

- 1999d. Biological Survey Report for Three Test Cell A Leachfield Sites. BN Letter from C. A. Wills to J. F. Bonn, Correspondence No. 2154-WO-99-0020, February 2, 1999.

- 1999e. Post-Activity Survey Report for GEOCORE Alignment Grid (\#99-06). BN Letter from C. A. Wills to S. B. Brewster, Correspondence No. 2154-WO-99-0022, February 8, 1999.

, 1999f. Biological Survey Report for CAU 321 (\#99-07). BN Letter from C. A. Wills to S. M. Parsons-DePry, Correspondence No. 2154-WO-99-0023, February 9, 1999.

, 1999g. Second Quarter Fiscal Year 1999 Monitoring of Manmade Water Sources on the Nevada Test Site. Submitted to U.S. Department of Energy, Nevada Operations Office, Letter from W. K. Ostler to R. C. Furlow, Correspondence No. 2154-WO-99-0026, March 3,1998 . 
1999h. Biological Survey Report for Characterization of Corrective Action Unit 240 (\#99-09). BN Letter from C. A. Wills to S. M. Parsons-DePry, Correspondence No. 2154-WO-99-0028, March 15, 1999.

1999i. Biological Survey Report for Clean Closure of U-2bu Subsidence Crater, Corrective Action Unit 109 (\#99-08). BN Letter from C. A. Wills to S. M. Parsons-DePry, Correspondence No. 2154-WO-99-0027, March 16, 1999.

1999j. Biological Survey Report for Off-road Driving Near the Army Research Laboratory (\#99-11). BN Letter from C. A. Wills to J. W. Schoppmann, Correspondence No. 2154-WO-99-0030, April 1, 1999.

, 1999k. Project Review for Remote Sensor Test Range Engineering Checkouts. Submitted to U.S. Department of Energy, Nevada Operations Office, Letter from W. K. Ostler to R. C. Furlow, Correspondence No. 2150-WO-99-0031, April 5, 1999.

19991. Biological Survey Report for CAU 263 (\#99-12). BN Letter from C. A. Wills to D. H. Cox, Correspondence No. 2154-WO-99-0032, April 8, 1999.

—, 1999m. Biological Survey Report for U1h Drainage Ditch (\#99-13). BN Letter from C. A. Wills to D. W. Rees, Correspondence No. 2154-WO-99-0034, April 15, 1999. , 1999n. Review of Off-gas Test for Inhibited Red Fuming Nitric Acid. Submitted to U.S. Department of Energy, Nevada Operations Office, Letter from W. K. Ostler to R. C. Furlow, Correspondence No. 2150-WO-99-0035, April 22, 1999.

19990. Review of Osprey I Test Plan - Safety Assessment Document. Submitted to U.S. Department of Energy, Nevada Operations Office, Letter from W. K. Ostler to R. C. Furlow, Correspondence No. 2150-WO-99-0036, April 22, 1999.

- , 1999p. Biological Survey Report for Stockade Wash Road Shoulder Maintenance. BN Letter from C. A. Wills to J. W. Schoppmann, Correspondence No. 2154-WO-99-0037, May 3, 1999.

, 1999q. Third Quarter Fiscal Year 1999 Monitoring of Manmade Water Sources on the Nevada Test Site. Submitted to U. S. Department of Energy, Nevada Operations Office, Letter from W. K. Ostler to R. C. Furlow, Correspondence No. 2154-WO-99-0041, May 27, 1999.

, 1999r. May 1999 Monitoring of Tortoise-Proof Fences at Well ER-5-2 and Areas 6 and 23 on the Nevada Test Site. Submitted to U.S. Department of Energy, Nevada Operations Office, Letter from C. A. Wills to R. C. Furlow, Correspondence No. 2154-WO-99-0042, June 8, 1999.

- 1999s. Biological Survey Report for Corrective Action Unit 232 (\#99-16), BN Letter from C. A. Wills to D.H. Cox, Correspondence No. 2154-WO-99-0046, July 12, 1999. 
, 1999t. Biological Survey Report for Corrective Action Unit 143 (\#99-18). BN Letter from C. A. Wills to J. L. Smith, Correspondence No. 2154-WO-99-0048, August 6, 1999.

, 1999u. Biological Survey Report for Sunrise 99 Project (\#99-10). BN Letter from

C. A. Wills to R. L. Mendenhall, Correspondence No. 2159-WO-99-0051, August 16, 1999.

1999v. Fourth Quarter Fiscal Year 1999 Monitoring of Manmade Water Sources on the Nevada Test Site. Submitted to U. S. Department of Energy, Nevada Operations Office, Letter from W. K. Ostler to R. C. Furlow, Correspondence No. 2154-WO-99-0055, September 13, 1999.

, 1999w. September 1999 Monitoring of Tortoise-Proof Fence at Well ER-5-2. Submitted to U. S. Department of Energy, Nevada Operations Office, Letter from

C. A. Wills to R. C. Furlow, Correspondence No. 2154-WO-99-0056, September 20, 1999.

Constantine, D. G., 1998. An overlooked external character to differentiate Myotis californicus and Myotis ciliolabrum (Vespertilionidae). Journal of Mammalogy, 79(2): 624-630.

Corben, C., Gannon, L. W., and M. J. O'Farrell, 1998. Techniques for the Effective Use of Anabat in Identifying Free-Flying Bat Species, Anabat Workshop Course Booklet. Bat Conservation International, Fort Collins, CO, May 19-20, 1998.

DOE (U.S. Department of Energy), 1994. Nevada Test Site Grid Map. U.S. Department of Energy, Nevada Operations Office, ER\&NP Division, Las Vegas, NV.

1996. Final Environmental Impact Statement for the Nevada Test Site and Off-Site Locations in the State of Nevada, Volume 1, Chapters 1-9. DOE/EIS 0243, U.S. Department of Energy, Nevada Operations Office, Las Vegas, NV, August 1996.

—, 1998. Nevada Test Site Resource Management Plan, DOE/NV-518, U.S. Department of Energy, Nevada Operations Office, Las Vegas, NV, December 1998.

EPA (U.S. Environmental Protection Agency), 1994. Guidance for the Data Quality Objectives Process. EPA QA/G-4. Quality Assurance Management Staff, Washington, D.C.

FWS (U.S. Fish and Wildlife Service), 1992. Procedures for Endangered Species Act Compliance for the Mojave Desert Tortoise. USDI Fish and Wildlife Service Regions 1, 2, and 6, October 1992.

1996. Final Programmatic Biological Opinion for Nevada Test Site Activities. File No. 1-5-96-F-33, August 22, 1996, U.S. Fish and Wildlife Service, Reno, NV.

Giles, K. R., 1976. Springs on the Nevada Test Site and Their Use by Wildlife. NERC-LV-539-26, U.S. Environmental Protection Agency, Las Vegas, NV, April 1976.

Greger, P. D. and E. M. Romney, 1994. Trends in Wildlife Utilization of Water Source and Adjacent Habitats at the Nevada Test Site 1989-91. In: Status of the Flora and Fauna on the Nevada Test Site 1989-91. Compiled by R. B. Hunter, DOE/NV/11432-57. 
Grossman, D. H., D. Faber-Langendoen, A. S. Weakley, M. Anderson, P. Bourgeron, R. Crawford, K. Goodin, S. Landaal, K. Metzler, K. D. Patterson, M. Pyne, M. Reid, and L. Sneddon, 1998. International classification of ecological communities: terrestrial vegetation of the United States. Volume I. The National Vegetation Classification System: development, status, and applications. The Nature Conservancy, Arlington, VA.

Hansen, D. J., P. D. Greger, C. A. Wills, and W. K. Ostler, 1997. Nevada Test Site Wetlands Assessment. DOE/NV/11718-124, Bechtel Nevada, Las Vegas, NV, May 1997.

Hansen, D. J., W. K. Ostler, and D. B. Hall, 1999. The Transition from Mojave Desert to Great Basin Desert on the Nevada Test Site. In: McArthur, E. Durant; Ostler, W. Kent; Wambolt, Carl L., comps. 1999. Proceedings: Shrubland Ecotones; 1998 August 12-14; Ephriam, UT. Proc. RMRS-P-00. Ogden, UT: U.S. Department of Agriculture, Forest Service, Rocky Mountain Research Station.

Hayward, C. L., M. L. Killpack, and G. L. Richards, 1963. Birds of the Nevada Test Site. Brigham Young University Science Bulletin, Vol. 3, No. 1, 27 pp.

Knight, T. and F. Smith, 1996. An Inventory for Rare, Threatened, Endangered, and Endemic Plants and Unique Communities on Nellis Air Force Bombing and Gunnery Range, Clark, Lincoln, and Nye Counties, Nevada, Volume III. U.S. Department of Defense Legacy Resource Management Program in cooperation with The Nature Conservance and Nellis Air Force Base, January 1996.

O'Farrell, M. J., 1997. Use of echolocation calls for the identification of free-flying bats. Transactions of the Western Section of the Wildlife Society, 33:1-8.

O’Farrell, M. J., B. W. Miller, and W. L. Gannon, 1999. Qualitative identification of free-flying bats using the Anabat detector. Journal of Mammalogy 80(1):11-23.

Ostler, W. K., D. J. Hansen, D. B. Hall, 1999. The Classification of Shrublands on the Nevada Test Site. In: McArthur, E. Durant; Ostler, W. Kent; Wambolt, Carl L., comps. 1999.

Proceedings: Shrubland Ecotones; 1998 August 12-14; Ephriam, UT. Proc. RMRS-P-00. Ogden, UT: U.S. Department of Agriculture, Forest Service, Rocky Mountain Research Station.

Steen, D. C., D. B. Hall, P. D. Greger, and C. A. Wills, 1997. Distribution of the Chuckwalla, Western Burrowing Owl, and Six Bat Species on the Nevada Test Site. DOE/NV/11718-149, Bechtel Nevada, Inc., Las Vegas, NV, May 1, 1997.

White, G. C., D. R. Anderson, K. P. Burnham, and D. L. Otis, 1982. Capture-Recapture and Removal Methods for Sampling Closed Populations. LA-8787-NERP, Los Alamos National Laboratory, Los Alamos, NM, August 1982.

Woodward, R., K. Rautenstrauch, D. Hall, and W. K. Ostler, 1998. The Abundance of Desert Tortoises on the Nevada Test Site Within Ecological Landform Units, DOE/NV/11718--245, Bechtel Nevada, Las Vegas, Nevada, September 1998. 
USDA (U.S. Department of Agriculture), NRCS 1996. The PLANTS Database. U.S. Department of Agriculture, National Resources Conservation Service, National Plant Data Center, Baton

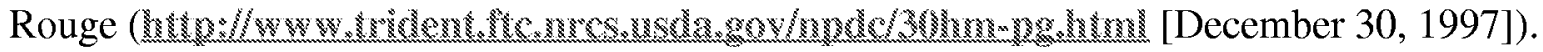

USDA, SCS 1982. National List of Scientific Plant Names. SCS-TP-159. U.S. Department of Agriculture, Soil Conservation Service, U.S. Government Printing Office. 
U.S. Department of Energy,

Nevada Operations Office

Las Vegas, Nevada

Robert Furlow, ESH (6)

Carl Gertz, AMEM

Kennith Hoar, ESHD

Kathy Izell, AMTS

Deborah Monette AMNS

Darwin Morgan, OPAI

Jay Norman, O/Mgr

Public Reading Facility

Technical Information Resource Center

U.S. Department of Energy,

Yucca Mountain Site Characterization Office

Las Vegas, Nevada

Wendy Dixon

Scott Wade

U.S. Bureau of Land Management

Las Vegas, Nevada

District Manager

U.S. Army Corps of Engineers

Reno, Nevada Kevin Rouke

U.S. Fish and Wildlife Service, Suboffice No. 1

Las Vegas Field Office

Las Vegas. Nevada

Janet Bair

U.S. Fish and Wildlife Service, Nevada State

Office

Reno. Nevada

Robert Williams

U.S. Geological Survey, Biological Resources

Division

Las Vegas, Nevada Philip Medica

Desert National Wildlife Refuge Complex Las Vegas, Nevada Richard Birger

Death Valley National Park

Death Vallev, California Richard Martin

National Park Service Lake Mead National Recreation Area Boulder City, Nevada Kent Turner

Nellis Air Force Base

Las Vegas, Nevada Susan Barrow

Ash Meadows National Wildlife Refuge Ash Meadows, Nevada Refuge Manager

Nevada Department of Wildlife, Region III Las Vegas, Nevada Mike Wickersham
Nevada Division of Forestry

Las Vegas, Nevada

John Jones

Nevada State Clearinghouse

Carson City, Nevada

David Ledig

Bechtel Nevada

Environmental Monitoring

North Las Vegas, Nevada Don Van Etten (8)

Defense Threat Reduction Agency

Mercury, Nevada Laurence Ashbaugh

Desert Research Institute

Las Vegas. Nevada David Shafer

University of Nevada Las Vegas,

Harry Reid Center for Environmental

Studies

Las Vegas, Nevada

Don Baepler

IT Corporation

Las Vegas, Nevada Mary Lou Brown

Nevada Natural Heritage Program

Carson City, Nevada Glenn Clemmer

Lawrence Livermore National Laboratory Las Vegas, Nevada Willie Cooper

Los Alamos National Laboratory

Las Vegas, Nevada Chuck Costa

Sandia National Laboratories

Las Vegas, Nevada Paul Raglin

The Nature Conservancy

Las Vegas, Nevada James Moore

DOE Office of Scientific and Technical Information

Oak Ridge, Tennessee (2) 